\title{
Modeling the metabolic fate of dietary phosphorus and calcium and the dynamics of body ash content in growing pigs 1,2
}

\author{
M. P. Létourneau-Montminy, ${ }^{* 3}$ A. Narcy, $\dagger$ J. Y. Dourmad, † T. D. Crenshaw, § and C. Pomar*4 \\ *Dairy and Swine Research and Development Centre, Agriculture and Agri-Food Canada, Sherbrooke, QC, J1M 1Z3, \\ Canada; $†$ INRA, UR83 Recherches Avicoles, F-37380 Nouzilly, France, \$INRA Agrocampus-Ouest, UMR1348 Pegase, \\ F-35590 Saint-Gilles, France; and §Department of Animal Science, University of Wisconsin-Madison, Madison 53706
}

\begin{abstract}
A better understanding of the fate of dietary $\mathrm{P}$ use by growing pigs will allow an optimization of $\mathrm{P}$ use and enhance sustainable practices. The optimization of $\mathrm{P}$ utilization is complicated by the multiple criteria, such as growth performance, bone mineralization, and manure $\mathrm{P}$ used for assessment of needs. Mathematical modeling is a useful tool to describe relevant biological mechanisms and predict relationships that describe the whole system behavior. Modeling allows development of robust multicriteria approaches to optimize $\mathrm{P}$ utilization, feeding cost, and manure application cost. This paper describes and evaluates a model developed to simulate the fate of dietary $\mathrm{P}$, that is, to simulate its digestive and metabolic utilization through digestion, soft tissue, and ash modules. The digestion module takes into account the varied sources of dietary minerals including responses to microbial and plant phytase and $\mathrm{Ca}$ and $\mathrm{P}$ interactions and predicts absorption and fecal excretion. The soft tissue module simulates the growth of the protein and is based on InraPorc model principles. The ash module simulates the partitioning of absorbed $\mathrm{Ca}$ and $\mathrm{P}$ into the bone, protein, and lipid compartments as well as urinary
\end{abstract}

excretion. Model behavior showed that the model was able to accurately represent the impact of Lys deficiency on $\mathrm{P}$ retention, of $\mathrm{Ca}$ and $\mathrm{P}$ imbalances, and of $\mathrm{Ca}$ and $\mathrm{P}$ depletion and repletion sequences. The model's prediction capabilities in simulating whole-body protein, $\mathrm{Ca}, \mathrm{P}$, and ash based on published data showed high accuracy, with a slope and intercept that did not differ from 1 and 0 , respectively, and an error due to disturbance (ED; variance not accounted for by regression of observed on predicted values). The model's prediction capabilities in simulating balance trial data showed good accuracy for apparent total tract digestibility (ATTD) of $\mathrm{P}$ (observed $=-0.77+1.06$ predicted) and $\mathrm{P}$ retention coefficient (observed $=-4.5+1.15$ predicted) with an ED of $89 \%$ for both criteria. The model's prediction capabilities in simulating $\mathrm{Ca}$ ATTD and Ca retention coefficient are lower (ED of 88 and $28 \%$, respectively). This model simulates body ash independently of body protein and accounts for the impact of past and current dietary $\mathrm{Ca}$ and $\mathrm{P}$ supply. That ability is essential for the real-time adaptation of mineral supplies to suit individual production objectives, which would contribute to the overall success of pig production.

Key words: ash, calcium, model, phosphorus, pig

\section{INTRODUCTION}

\footnotetext{
${ }^{1}$ This research was funded by the Matching Investment Initiative of Agriculture and Agri-Food Canada.

${ }^{2}$ The authors are grateful for useful advice and suggestions from Dr. Hans Stein and Caroline González-Vega.

${ }^{3}$ Present address: Department of Animal Science, Laval University, Quebec City, QC, G1V 0A6, Canada.

${ }^{4}$ Corresponding author: Candido.Pomar@agr.gc.ca

Received September 18, 2014.

Accepted December 24, 2014.
}

Establishing the amount of $\mathrm{P}$ to supplement into diets remains an important issue for pig production. Multiple response criteria are used depending on the production objectives (e.g., profitability, animal welfare, and environment) making the concept of establishing a single requirement challenging. Therefore, multicriteria approaches should be used to handle the complexity of the animal response to minerals. 
More than two-thirds of body $\mathrm{P}$ and more than $95 \%$ of body $\mathrm{Ca}$ is found in the pig skeleton bound together to form hydroxyapatite $\left(\mathrm{Ca}_{10}\left(\mathrm{PO}_{4}\right)_{6}\right.$; Crenshaw, 2001). The deposition of $\mathrm{Ca}$ and $\mathrm{P}$ into bone is, therefore, strictly dependent on the presence of the other mineral. The remainder of body $\mathrm{P}$ is found mainly in muscle tissues (Nielsen, 1973) where it serves several vital mechanisms and has no common function with $\mathrm{Ca}$. The concentration of $\mathrm{Ca}$ and $\mathrm{P}$ in skeletal tissue depends mainly on dietary supply, whereas the concentration of $\mathrm{P}$ in soft tissue is fixed and has a priority over $\mathrm{P}$ deposition into bone (Feaster et al., 1953; Brautbar et al., 1979).

It is generally recognized that in growing animals, bone development initially increases faster than muscle but then declines as muscle tissue continues to increase (Mahan, 1978). Given this body partitioning, the assessment of $\mathrm{Ca}$ and $\mathrm{P}$ requirements must consider the fact that changes in skeletal tissue are not directly proportional to lean growth (Pomar et al., 2006; Gonzalo et al., 2014). Lean tissue and bone content are affected by genotype, which leads to different $\mathrm{P}$ requirements and responses to dietary $\mathrm{P}$ between genotypes (Hittmeier et al., 2006; Alexander et al., 2008). In addition, P- and Cadepleted pigs have the capacity to rapidly replace bone mass through compensatory bone mineralization (Ryan et al., 2011; Varley et al., 2011a; Gonzalo et al., 2014; Létourneau-Montminy et al., 2014). This implies that similar production objectives (e.g., same bone mass) can be achieved with different feeding strategies with a sequence of diets differing in P content. Understanding and simulating the growth of both tissues are, therefore, fundamental to the establishment of $\mathrm{P}$ and $\mathrm{Ca}$ requirements.

The objective of this study was to develop a robust deterministic and mechanistic research model, which 1) simulates $\mathrm{Ca}$ and $\mathrm{P}$ retention within different anatomical compartments of the pig in response to animal growth potential and dietary $\mathrm{Ca}$ and $\mathrm{P}$ intake and 2) evaluates the impact on the pig of giving them deficient and imbalanced diets.

\section{MATERIALS AND METHODS}

\section{General Statements}

In many current pig-growth models (van Milgen et al., 2008; NRC, 2012), empty BW is defined as the algebraic sum of the main chemical components of the empty animal body, which are total body water, protein, lipid, and ash as suggested earlier by Whittemore and Fawcett (1976). Protein was calculated throughout the text as $\mathrm{N} \times 6.25$. In the current animal growth models, the relationships between chemical body constituents have been adapted and updated with recent experimental data to represent modern pig breeds. Rather than use body components that result from dissection or any other physical measurements, these models choose chemical constituents of the body to represent pig body composition, as physical body components are numerous and their development during growth and the reproductive cycle is not well known. The proposed chemical body constituents are more easily represented in mathematical models because they can be reduced to only 2 variables, namely protein and lipid. The accretion of these variables can be described independently of the tissues in which they accumulate (Pomar et al., 1991a,b,c). For example, van Milgen et al. (2008) suggested that empty $\mathrm{BW}$ and BW can be estimated from protein and lipid body masses, estimated based on Quiniou and Noblet (1995), with water and ash embedded within these 2 body constituents. A similar approach was recently proposed by the NRC (2012). This modeling approach implies that body ash (all body minerals) is linked to body protein and, therefore, that body ash mass and growth are driven by growth of body protein mass, as observed in pigs fed diets that are formulated to maximize bone mineralization (Rymarz et al., 1982; Hendriks and Moughan, 1993; Mahan and Shields, 1998). However, pigs that were not fed such diets modulate soft tissue growth and bone mineralization independently (Pomar et al., 2006; Rousseau, 2013), and in these circumstances, body ash can be reduced without necessarily reducing soft tissue growth (Fig. 1).

For a more accurate representation of the metabolic fate of dietary $\mathrm{Ca}$ and $\mathrm{P}$ and ash retention, especially in pigs fed mineral-deficient diets for bone mineralization, the ash and protein body components of current pig growth models need to be dissociated. Body ash is found in bones (AshBn) and soft tissues (AshSt) at the ratio of 78:22 in pigs fed diets formulated to maximize bone mineralization (Nielsen, 1973). Indeed, AshBn includes $\mathrm{Ca}, \mathrm{P}$, and bone miscellaneous minerals (MiscBn) that are deposited into the bone at fixed ratios (Crenshaw, 2001). In the current model, the representation of miscellaneous minerals (Misc) is a way to fill the gap between $\mathrm{Ca}, \mathrm{P}$ and total AshBn and AshSt. It is, therefore, the sum of other minerals than $\mathrm{Ca}$ and $\mathrm{P}$ found in fluids and organs including bone, bile, liver, and kidney. The relationship between soft tissue growth and bone growth is not well established, but changes in skeletal tissues are not proportional to lean growth; skeletal growth is assumed to precede that of soft tissue (Mahan, 1978). It should be noted that this relationship is probably more related to bone length than bone weight or ash content. Therefore, in current commercial breeds, fed at a level maximizing bone mineralization, it is possible that the skeleton mineralization (ash content) and muscles accumulate at comparable rates $(\mathrm{g} / \mathrm{kg}$ mature $\mathrm{BW})$ relative to mature body mass. Because of the lack of precise 


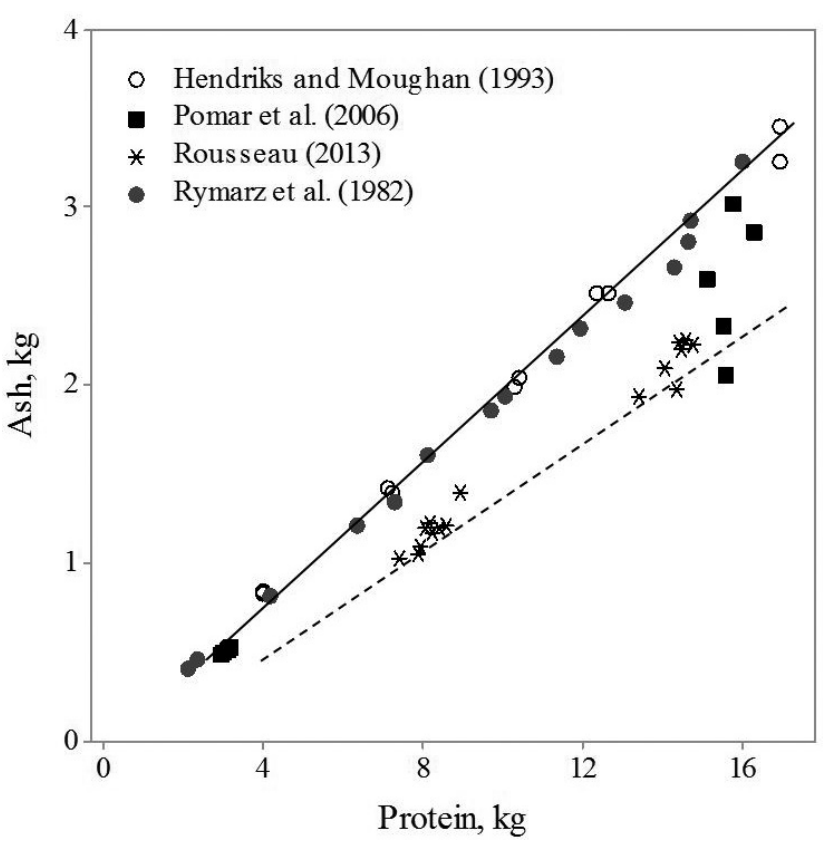

Figure 1. Relationship between whole-body ash and protein in growing pigs fed at requirements (full line) or with deficient $\mathrm{Ca}$ and $\mathrm{P}$ diets (dashed line).

information about potential bone mineralization in pigs, the potential $\mathrm{Ca}$ retention in bones (potential $\mathrm{Ca}$ in bone $[\mathbf{C a B n}]$ retention) is commonly proposed to be driven by potential protein retention, which is assumed to be an animal or breed phenotypic trait affected by production conditions such as stocking density and sanitary conditions in animals fed ad libitum and in the absence of limiting factors (van Milgen et al., 2008; NRC, 2012). In the proposed model, protein and total body potential protein mass are both model fixed variables that drive, respectively, protein retention and potential protein retention rate variables. These actual and potential state variables will differ when the animal cannot express its full growth potential, thus allowing $\mathrm{CaBn}$ and protein to evolve separately under limiting growth conditions. The phenotypic body protein potential is used in this model to drive potential protein retention and bone growth and does not interact with protein growth.

\section{General Structure of the Model}

The proposed mathematical model has 3 modules, namely digestion, soft tissue, and ash. The digestion module estimates the amounts of nutrients that are absorbed in the gastrointestinal tract and the amounts excreted in feces. The soft tissue module then simulates the metabolic utilization of dietary nutrients other than minerals into protein and lipid (fixed variables). This module represents the dynamics of protein and lipid masses and retention but excludes the amounts of minerals associated with them (Fig. 2). Soft tissue growth is represented in this model using the InraPorc pig-growth model (van Milgen et al., 2008), but other models to predict soft tissue growth (i.e., NRC, 2012) can be easily incorporated. Finally, the ash module simulates the fate of the absorbed dietary $\mathrm{Ca}$ and $\mathrm{P}$ in terms of their retention in soft tissue (i.e., AshSt) and bone (i.e., AshBn) and their urinary excretion. The AshSt body component is driven by the total body protein and lipid as simulated in the soft tissue module. The ash module includes 2 additional fixed variables, namely the potential amount of $\mathrm{Ca}$ in bone (potential $\mathrm{CaBn}$ ), which represents the dynamics of bone mass under nonlimiting conditions, and actual $\mathrm{CaBn}$, which is dependent on dietary $\mathrm{P}$ and Ca supply.

Absorbed dietary $\mathrm{Ca}, \mathrm{P}$, and (Misc) pass through the extracellular fluid before they are retained in soft tissue and bones or excreted in urine. This extracellular compartment is treated as a zero pool, thus representing the small amount of these minerals in body fluids and the strong hormonal regulations (e.g., parathyroid hormone, vitamin D; Crenshaw, 2001) that maintain these pools at near-constant concentrations. The proposed model was written with ModelMaker (version 4; ModelKinetix, Wallingford, UK), having day as the time unit and using the Runge-Kutta method (Thornley and France, 2006) for differential equation integration. Model parameter values are presented in Table 1. State variables are expressed in grams and rate variables in grams per day. The terminology used in the text is similar to that proposed by Whittemore (1983), which characterizes parameters or equations as hard data (statements with adequate proof), soft data (statements with inadequate, but some, proof), and estimates and conjecture.

\section{Calcium and Phosphorus Digestion and Absorption}

Dietary $\mathrm{Ca}$ and $\mathrm{P}$ are absorbed in the small intestine through a combination of active and passive flows (Fox et al., 1978) after complex digestion processes such as solubilization, insolublization, transition, and hydrolysis. The representation of $\mathrm{Ca}$ and $\mathrm{P}$ flows from the gastrointestinal tract to the extracellular fluids is a simplification of the model that described the fate of dietary $\mathrm{Ca}$ and $\mathrm{P}$ in the digestive tract of growing pigs (Létourneau-Montminy et al., 2011).

In this model, ad libitum feed intake is an input variable that is assumed to be modulated mainly by BW, as proposed in the InraPorc model (van Milgen et al., 2008), in which the desired NE intake is driven by BW. Feed intake includes qualitative and quantitative descriptions of the feed. Dietary P enters the gastrointestinal tract P pool in the form of phytate $\mathrm{P}$ or nonphytate P. All the ingested phytate $\mathrm{P}$ is assumed to be from plant materials, whereas nonphytate $\mathrm{P}$ can be of plant origin or mineral and animal origin. Dietary $\mathrm{Ca}$ enters the gastrointestinal 

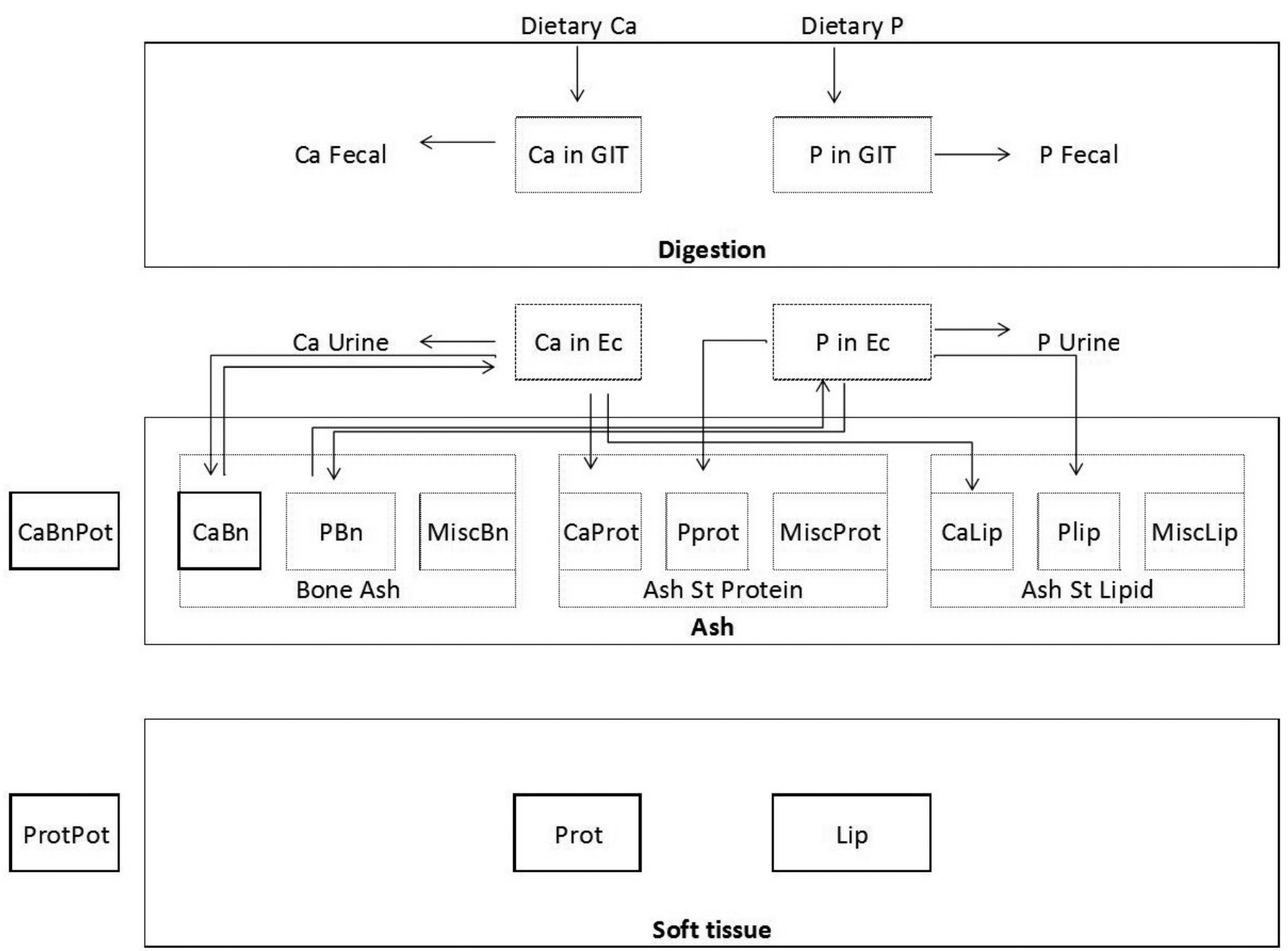

Figure 2. Model diagram. Boxes enclosed by large solid lines are state variables, dashed lines are zero pools and fine lines are auxiliary variables. Arrows indicate flows. $\mathrm{GIT}=$ the gastrointestinal track; $\mathrm{EC}=$ extracellular fluids; $\mathrm{CaBnPot}=$ maximal $($ potential) $\mathrm{Ca}$ in bone; $\mathrm{CaBn}=\mathrm{Ca}$ in bone; $\mathrm{PBn}=\mathrm{P}$ in bone; $\mathrm{MiscBn}=$ Miscellaneous minerals in bone; $\mathrm{CaProt}=\mathrm{Ca}$ associated with protein in soft tissues; $\mathrm{Pprot}=\mathrm{P}$ associated with protein in soft tissues; MiscProt $=$ Miscellaneous minerals associated with protein in soft tissues; $\mathrm{CaLip}=\mathrm{Ca}$ associated with lipids in soft tissues; $\mathrm{Plip}=\mathrm{P}$ associated with lipids in soft tissues; MiscLip $=$ Miscellaneous minerals associated with lipids in soft tissues; $\mathrm{St}=$ soft tissue; ProtPot = Body protein potential; Prot = Body protein mass; Lip = Body lipid mass.

tract $\mathrm{Ca}$ pool in its total form. The intake of each dietary $\mathrm{P}$ form and total $\mathrm{Ca}$ is obtained by the product of the respective feed concentration and feed intake.

Endogenous $\mathrm{Ca}$ and $\mathrm{P}$ originate from the bile, duodenal pancreatic secretions, and the desquamation of intestinal epithelial cells. These mineral fluxes have not been independently measured and are therefore not represented in the digestion module of the proposed model. Therefore, when the amounts of absorbed $\mathrm{P}$ and $\mathrm{Ca}(\mathrm{Eq}$. [1] and [2]) and the amounts of fecal $\mathrm{P}$ and fecal $\mathrm{Ca}$ are calculated, the nonabsorbed endogenous secretions (fecal endogenous losses) have to be removed by the model from the amount absorbed. Endogenous P losses may be separated into basal losses, which are not influenced by feed ingredient composition, and specific losses, which are induced by feed ingredient characteristics such as levels and types of fiber and antinutritional factors. Given that absorption is based on apparent total tract digestibility (ATTD) data, both basal and specific losses need to be removed. However, specific losses are difficult to measure and most literature concerns basal losses. Therefore, we have used the value of $0.190 \mathrm{~g} / \mathrm{kg}$ DMI for the fecal endogenous P losses (fecal EPL, NRC, 2012), corresponding to the average losses found in literature (Schulin-Zeuthen et al., 2007; Dilger and Adeola, 2006). It should be noted, however, that some authors found, for an unknown reason, really higher values around $0.5 \mathrm{~g} / \mathrm{kg}$ DMI (Fan and Sauer, 2002; Ajakaiye et al., 2003; Shen et al., 2002). Data on fecal endogenous $\mathrm{Ca}$ losses (fecal ECaL) are more limiting and the recent value of $0.174 \mathrm{~g} / \mathrm{kg}$ DMI has been used (González-Vega et al., 2013). Given the variation in fecal EPL, it can be considered a soft data, and data on fecal ECaL are softer, given that they have been measured in fewer studies.

The ATTD of the dietary phytate $\mathrm{P}$ and nonphytate $\mathrm{P}$ from plant forms were previously estimated (LétourneauMontminy et al., 2011, 2012). For nonphytate P from mineral and animal origin, the P ATTD reported in Sauvant et al. (2004) was used (Table 1). However, these 
Table 1. Description, abbreviation, and amount of the model parameters

\begin{tabular}{|c|c|c|}
\hline Description of model parameters & Abbreviation & Value \\
\hline Apparent total tract digestibility of $\mathrm{Ca}$ linear parameter & ATTD-Ca Linear & 0.83 \\
\hline Apparent total tract digestibility of $\mathrm{Ca}$ quadratic parameter & ATTD-Ca Quadratic & -0.02 \\
\hline Apparent total tract digestibility of nonphytate $\mathrm{P}$ from dicalcium phosphate & ATTD-nonphytate DCP & 0.78 \\
\hline Apparent total tract digestibility of nonphytate $\mathrm{P}$ from lactoserum & ATTD-nonphytate Lacto & 0.90 \\
\hline Apparent total tract digestibility of nonphytate $\mathrm{P}$ from mineral-animal & ATTD-nonphytate mineral-animal & 0.78 \\
\hline Apparent total tract digestibility of nonphytate $\mathrm{P}$ from monocalcium phosphate & ATTD-nonphytate MCP & 0.92 \\
\hline Apparent total tract digestibility of nonphytate $\mathrm{P}$ from monosodium phosphate & ATTD-nonphytate MSP & 0.98 \\
\hline Apparent total tract digestibility of nonphytate $\mathrm{P}$ from plant & ATTD-nonphytate P plant & 0.73 \\
\hline Apparent total tract digestibility of phytate $\mathrm{P}$ & ATTD-phytate P & 0.21 \\
\hline Fecal endogenous losses of $\mathrm{Ca}$ & Fecal ECaL & $0.190 \mathrm{mg} / \mathrm{kg} \mathrm{DMl}$ \\
\hline Fecal endogenous losses of $\mathrm{P}$ & Fecal EPL & $0.139 \mathrm{mg} / \mathrm{kg} \mathrm{DMI}$ \\
\hline Formation of insoluble complexes of Ca-NPP & Ca-nonphytate $\mathrm{P}$ & -0.0333 \\
\hline Formation of insoluble complexes of Ca-PP & Ca-phytate P & -0.32 \\
\hline Parameter of whole-body water estimation & $a$ & 5.3 \\
\hline Parameter of whole-body water estimation & $b$ & 0.855 \\
\hline Percentage of whole-body calcium in bone & Percentage $\mathrm{CaBn}$ & 0.99 \\
\hline Precocity coefficient of the Gompertz function & Precocity & 0.02 \\
\hline Proportion of lipid in subcutaneous fat & Lip:SubFat & 0.93 \\
\hline Proportion of miscellaneous in bone ash & Misc:AshBn & 0.43 \\
\hline Proportion of miscellaneous in muscle & Misc:Musc & 2.4 \\
\hline Proportion of miscellaneous in subcutaneous fat & Misc:SubFat & 0.26 \\
\hline Proportion of P in muscle & P:Musc & 0.59 \\
\hline Proportion of $\mathrm{P}$ in subcutaneous fat & P:SubFat & 0.05 \\
\hline Proportion of protein in muscle & Protein:Musc & 0.58 \\
\hline Ratio of $\mathrm{Ca}$ to $\mathrm{P}$ in bone & $\mathrm{Ca}: \mathrm{PBn}$ & 2.2 \\
\hline Ratio of Ca to protein in whole-body & Ca:protein & 0.05 \\
\hline Urine endogenous losses of $\mathrm{Ca}$ & Urine ECaL & $2.0 \mathrm{mg} / \mathrm{kg} \mathrm{BW}$ \\
\hline Urine endogenous losses of $\mathrm{P}$ & Urine EPL & $0.5 \mathrm{mg} / \mathrm{kg} \mathrm{BW}$ \\
\hline
\end{tabular}

P ATTD values were considered hard data, given the large amount of information about them in the literature. For total $\mathrm{Ca}$, however, a similar database and meta-analysis approaches were used to develop the equation, but the studies were built mainly to study low-P diets, and therefore, the data for Ca ATTD are soft. Although the ATTD of each P form is independent of its supply and, therefore, was assumed to be constant, Ca ATTD is curvilinear and decreases as levels of dietary $\mathrm{Ca}$ increase. A negative effect of dietary $\mathrm{Ca}$ on $\mathrm{P}$ absorption through the formation of insoluble complexes of $\mathrm{Ca}$ and nonphytate $\mathrm{P}$ (Ca-nonphytate P; Charles, 1992; Heaney and Nordin, 2002; González-Vega et al., 2013) as well as a negative impact of dietary phytate $\mathrm{P}$ on $\mathrm{Ca}$ absorption through the formation of insoluble complexes of $\mathrm{Ca}$ and phytate $\mathrm{P}$ (Ca-phytate P; Selle et al., 2009). The capacity of microbial phytase and plant phytase to improve P ATTD is clearly hard data, because it is well known and is commonly used to formulate diets (Selle and Ravindran, 2008). The $P$ and $C a$ phytase equivalencies represent the amount of these inorganic minerals that can be replaced by microbial or plant phytase. In the model, similar equivalencies are used for $\mathrm{P}$ and $\mathrm{Ca}$. Phytase equivalencies for $\mathrm{P}$ are calculated based on the EvaPig principles
(EvaPig software, version 1.3.1.4; INRA, Saint-Gilles, France), which assume an exponential response between the incorporation of Aspergillus niger phytase (Kornegay, 2001) and of plant phytase on phytate hydrolysis. Plant phytase activity is considered only in nonpelleted feeds, and its $\mathrm{P}$ equivalency value was assumed to be half of that of microbial phytase (Zimmermann et al., 2003; Létourneau-Montminy et al., 2012) with a maximum of $0.4 \mathrm{~g}$ digestible $\mathrm{P}$ (Jondreville and Dourmad, 2005). The interaction between microbial and plant phytase was also taken into account given that they compete for the same substrate. The interaction between phytate and phytase were assumed to be negligible, as shown by LétourneauMontminy et al. (2011, 2012).

Phosphorus and $\mathrm{Ca}$ absorption are calculated as follows:

absorbed P $=-$ Fecal EPL $\times$ DMI $+($ ATTD-phytate $\mathrm{P} \times$ phytate $\mathrm{P})+($ ATTD-nonphytate $\mathrm{P}$ plant $\times$ nonphytate $\mathrm{P}$ plant $)+($ ATTD-nonphytate $\mathrm{P}$ mineral-animal $\times$ nonphytate $\mathrm{P}$ mineral-animal $)-(\mathrm{Ca}-$ nonphytate $\mathrm{P} \times \mathrm{Ca})+\mathrm{P}$ equivalency microbial phytase $+\mathrm{P}$ equivalency plant phytase and 
absorbed $\mathrm{Ca}=-$ Fecal ECaL $\times$ DMI $+($ ATTD-Ca Linear $\times \mathrm{Ca})+\left(\right.$ ATTD-Ca Quadratic $\left.\times \mathrm{Ca}^{2}\right)-(\mathrm{Ca}-$ phytate $\mathrm{P} \times \mathrm{Ca} \times$ phytate $\mathrm{P})+\mathrm{Ca}$ equivalency microbial phytase $+\mathrm{Ca}$ equivalency plant phytase, [2]

in which absorbed $\mathrm{P}$ and $\mathrm{Ca}$ are measured in grams/day; fecal EPL and ECaL are the fecal endogenous $\mathrm{P}$ and $\mathrm{Ca}$ losses, respectively; ATTD-Ca Linear and ATTDCa Quadratic are the linear and quadratic parameters, respectively, used to estimate the ATTD of dietary $\mathrm{Ca}$ in feeds; the $\mathrm{Ca}$-phytate $\mathrm{P}$ is the interaction representing the negative impact of phytate $\mathrm{P}$ on the availability of Ca for absorption, and ATTD-phytate P, ATTDnonphytate $\mathrm{P}$ and ATTD-nonphytate $\mathrm{P}$ mineral-animal are respectively the ATTD of phytate $\mathrm{P}$, nonphytate $\mathrm{P}$ of plant origin and nonphytate $\mathrm{P}$ of animal origin.

Nonabsorbed dietary $\mathrm{Ca}$ and $\mathrm{P}$ are excreted via feces and are estimated as follows:

P excreted in feces $=\mathrm{P}$ intake - absorbed $\mathrm{P}$, and [3]

Ca excreted in feces $=\mathrm{Ca}$ intake - absorbed $\mathrm{Ca}$, [4]

given that fecal $\mathrm{Ca}$ and $\mathrm{P}$ endogenous losses have already been removed from absorbed $\mathrm{Ca}$ and absorbed P flows as calculated in Eq. [1] and [2], respectively.

\section{Soft Tissue Growth}

Protein and lipid deposition were simulated as suggested by van Milgen et al. (2008). The fixed variables protein and lipid are updated daily by the numerical integration of the corresponding differential equations. The difference between potential protein and protein represents the deficit in body protein mass. Water is still estimated from protein as in current pig-growth models and is predicted in the present model as suggested by de Lange et al. (2003). In comparison with other growth models, the present model's estimate of total body ash is not directly dependent on protein and protein deposition, and its representation is described in the following section. Noteworthy in the present model, potential protein is an animal phenotypic trait independent of past and current production conditions, whereas protein, and the amount of protein that can be retained by a pig in a given situation, is driven by the animal's actual state (i.e., protein) and its phenotypic potential. For instance, in the InraPorc model (van Milgen et al., 2008), actual protein retention is driven by the actual state of protein and, therefore, some compensatory protein growth can occur (van Milgen et al., 2008). Therefore, after a period of feed restriction resulting in reduced protein retention, pigs are able to pursue their protein growth without losses in potential protein retention.

\section{The Metabolic Fate of the Absorbed Calcium and Phosphorus}

Extracellular Fluid Ash. Animals present homeostatic mechanisms, including complex hormonal regulations that control the absorption of dietary $\mathrm{Ca}$ and $\mathrm{P}$ from feeds and regulate their distributions in the body. This phenomenon is especially true for the extracellular concentration of $\mathrm{Ca}$, which is maintained within a relatively narrow range at a constant concentration over time, independent of diet supplementations or bone reserves (Bronner and Stein, 1995). The concentration of $\mathrm{P}$ in extracellular fluids is less rigidly maintained but has hormonal regulation pathways similar to those of $\mathrm{Ca}$. The difference between these minerals' control of extracellular concentration can be the result of different $P$ and Ca regulating hormones affecting digestion, absorption, and renal excretion of $\mathrm{Ca}$ and $\mathrm{P}$ (Crenshaw et al., 2011).

Nonetheless, although $\mathrm{Ca}$ and $\mathrm{P}$ concentrations in extracellular fluid pools are critical in their physiological contributions to osmotic balance and cation-anion equilibrium, they are not quantitatively important to total body mass balance. Therefore, extracellular $\mathrm{Ca}$ and $\mathrm{P}$ pools were not represented in pig growth models aiming to quantify the utilization of dietary minerals. Therefore, $\mathrm{Ca}$, $\mathrm{P}$, and Misc in extracellular fluids are represented in the model as zero pools, that is, the inputs equal the outputs.

Soft Tissue Ash. The composition of AshSt is not well known, but considering a Ca:P whole-body ratio around 1.65 and a fixed $\mathrm{Ca}: \mathrm{P}$ ratio of 2.2 in bone with most of whole-body $\mathrm{Ca}$ found in bone (Crenshaw, 2001), it can be assumed that about $30 \%$ of total body $\mathrm{P}$ is found in soft tissues, mainly muscles and entrails (Nielsen, 1973; Wiseman et al., 2009). The concentration of $\mathrm{P}$ in soft tissues can be assumed to be constant, as shown in rats with severely P-deficient diets (Feaster et al., 1953; Brautbar et al., 1979); however, the total accumulation of $\mathrm{P}$ is directly proportional to accumulation of soft tissue. The current model assumed, therefore, that P required for soft tissue growth has priority over the $\mathrm{P}$ required for bone retention. The same prioritization mechanisms were applied in the present model to $\mathrm{Ca}$, although the impact of this priority is negligible given that $\mathrm{Ca}$ in soft tissues represents less than $1 \%$ the total body Ca (Nielsen, 1973).

Pig dissection data (Nielsen, 1973) were used to estimate the amount of $\mathrm{P}$ and $\mathrm{Ca}$ in soft tissues, with the assumption of that muscle mineral composition adequately represented the amount of minerals retained with protein. Similarly, the mineral composition of subcutaneous fat has been used to represent 
the amount of minerals retained with total body lipid. Therefore, protein is assumed in the present model to be associated with a lean tissue containing $0.59 \% \mathrm{P}$, $0.02 \% \mathrm{Ca}$, and $2.39 \%$ Misc. Similarly, lipid is associated with fat tissue containing $0.05 \% \mathrm{P}, 0.01 \% \mathrm{Ca}$, and $0.25 \%$ Misc minerals. Minerals in soft tissues (i.e., AshSt) were obtained from summation of the amounts of $\mathrm{Ca}, \mathrm{P}$, and Misc associated with protein and lipid. Given that these parameters values were from only 1 study, they are soft data.

Bone Ash. In contrast with current pig-growth models, the proposed model assumes that actual deposition of $\mathrm{Ca}$ in bones is driven by the amount and balance of the available $\mathrm{Ca}$ and $\mathrm{P}$ supply. Dietary $\mathrm{Ca}$ or $\mathrm{P}$ deprivation would impair bone growth (i.e., AshBn) without reducing AshSt.

Bone ash contains $39 \% \mathrm{Ca}, 54 \% \mathrm{PO}_{4}(18 \% \mathrm{P})$, and $7 \%$ miscellaneous material (Crenshaw, 2001). The composition of elements contained in miscellaneous material is not well known, but major elements in it are $\mathrm{Na}, \mathrm{K}, \mathrm{Mg}$, and trace minerals (Fe, $\mathrm{Mn}, \mathrm{Sr}, \mathrm{Zn}$, and $\mathrm{Cu}$ ). However, those minerals are assumed to be provided at adequate levels, and although their total amounts are quantified in the present model, they are assumed to not affect soft tissue or bone growth. In bone, $\mathrm{Ca}$ and $\mathrm{P}$ are deposited together in a fixed ratio of 2.2:1, which corresponds to the ratio found in bone hydroxyapatite (Crenshaw, 2001). In the present model, potential $\mathrm{CaBn}$ and $\mathrm{CaBn}$ are 2 fixed variables driving $\mathrm{Ca}, \mathrm{P}$, and Misc mineral retention and $\mathrm{AshBn}$ is the sum of actual $\mathrm{CaBn}$, $\mathrm{P}$ in bone (PBn), and Misc in bone (MiscBn). The difference between potential $\mathrm{CaBn}$ and actual $\mathrm{CaBn}$ measures the deficit in bone mineralization. Because of a lack of information for characterizing the bone mineralization potential of an actual pig, potential $\mathrm{CaBn}$ retention is assumed to be driven by potential protein retention and is calculated as follows:

potential $\mathrm{CaBn}$ retention $=$ potential protein retention $\times$ percentage $\mathrm{CaBn} \times \mathrm{Ca}$ :protein,

in which potential $\mathrm{CaBn}$ retention is measured in grams/ day, percentage $\mathrm{CaBn}$ represents the percentage of whole body $\mathrm{Ca}$ found in bones (Crenshaw, 2001), and Ca:protein is the ratio between the amount of $\mathrm{Ca}$ and protein found in the whole body of a pig fed to maximize bone mineralization and soft tissue growth (Pomar et al., 2006). The ratio between body $\mathrm{Ca}$ and protein is proposed as a model input parameter that assumes that this value may vary between pig genetic lines. The phenotypic potential protein retention is driven in this model by the current potential protein state of the pig (i.e., potential protein) using equations similar to those used to estimate actual protein retention. Although the current protein retention in soft tissues is driven by the current protein state, which can be affected by current and previous nutrition, potential protein retention is driven by potential protein, which is independent of any nutritional or environmental limiting factor.

The compensatory growth capacity of bone was assumed to be greater than that of protein. Indeed, the ability of pigs to fully recover from bone growth deprivation was previously shown, where concomitant deficiencies in dietary $\mathrm{Ca}$ and $\mathrm{P}$ improved their digestive and metabolic utilization during both the depletion and the subsequent repletion phases (Aiyangar et al., 2010; Varley et al., 2011a; Létourneau-Montminy et al., 2014). It should be noted that these studies concerned pigs with normal vitamin D status and has to be validated in pigs with questionable vitamin $\mathrm{D}$ status. The increased utilization of $\mathrm{Ca}$ and $\mathrm{P}$ is probably the sum of the increases in active intestinal absorption, kidney reabsorption, and bone mineral retention (Suttle, 2010), but exact partitioning and timing are not known and require additional research. Nevertheless, compensatory bone mineral retention was allowed in the model when dietary $\mathrm{Ca}$ and $\mathrm{P}$ are sufficient and driven by $\mathrm{CaBn}$ deficit. A simple mechanism allowing an increase in potential $\mathrm{CaBn}$ retention, proportional to $\mathrm{CaBn}$ deficit, has been included. For example, a $\mathrm{CaBn}$ deficit of $30 \%$ will induce a $\mathrm{CaBn}$ retention of 1.3 times the potential, a value that will decrease proportionally as the $\mathrm{CaBn}$ deficit decreases until bone recovery (i.e., $\mathrm{CaBn}$ deficit $=0$ ). The bone mineral status of the animal was, therefore, the driving force of bone mineral retention potential.

As stated above, soft tissue has essential $\mathrm{P}$ requirements to maintain vital functions. Day and McCollum (1939) reported that rats fed a P-deficient diet released $P$ from the skeleton and transferred $P$ to soft tissues until the depletion of mineral bone reserves reached dramatic levels. Therefore, if the dietary supply cannot satisfy the needs for soft tissue growth, bone mineral reserves are mobilized to preserve protein and lipid growth. Because of the fixed $\mathrm{Ca}$ to $\mathrm{P}$ ratio found in the hydroxyapatite components of bones and the assumption that the concentration of other minerals vary in the same proportions as $\mathrm{Ca}$ and $\mathrm{P}$, all bone minerals are mobilized at the level of the most limiting one, and excess minerals are excreted in urine. Part of the excess minerals can be managed through decreased intestinal absorption or fixation in other tissues, but these mechanisms were not considered in the present model. The maximum amount of minerals that can be mobilized from bone is not known. In a trial where pigs at $20 \mathrm{~kg} \mathrm{BW}$ received a P-free diet for $10 \mathrm{~d}$, the whole-body bone mineral content decreased by 50\% (E. Gonzalo, Agriculture and Agri-Food Canada, Sherbrooke, Canada, personal communication). Pigs fed a diet free of mineral $\mathrm{Ca}$ sources for 4 wk displayed a 
$35 \%$ decrease in bone mineralization with no effects on growth in comparison to control pigs (Eklou-Kalonji et al., 1999). Nonetheless, given the limited information available to quantify the amount of minerals that are mobilized from bones in low-mineral or mineral-free diets, this model is limited to a maximum bone deficit of $50 \%$.

Pigs reduce soft tissue growth if fed protein- or energy-deficient diets (Platt and Stewart, 1962), which is not necessarily the case for P-deficient diets (LétourneauMontminy et al., 2014). Reduced soft tissue growth is not necessarily accompanied by a decrease in bone mineralization or bone mineral retention. Pigs fed at 60 or $70 \%$ of the estimated Lys requirements reduced protein deposition by 27 and $25 \%$, respectively, and ADG by 25 and $20 \%$, respectively, but in both cases total body mineral content and its deposition $(\mathrm{g} / \mathrm{d})$ was not reduced (Zhang et al., 2012; Cloutier et al., 2014). Although such dietary nutrient deficiencies are seldom observed in practice, these results demonstrated that soft tissues and body ash may accumulate by independent mechanisms. Nevertheless, the present model arbitrarily assumes that bone growth decreased linearly when protein deposition was less than $70 \%$ of the current potential and reaches nil deposition at zero protein growth.

\section{Calcium and Phosphorus Urinary Excretion}

Urinary $\mathrm{Ca}$ and $\mathrm{P}$ include the obligatory losses and the amount of the minerals that cannot be retained in soft tissue or bone because of an imbalance between minerals or because of excesses. In pigs fed low amounts of $\mathrm{Ca}$ and $\mathrm{P}$, almost all $\mathrm{Ca}$ and $\mathrm{P}$ are reabsorbed by the kidney (Vipperman et al., 1974; Rodehutscord et al., 1998). Obligatory urinary losses of $\mathrm{Ca}$ and $\mathrm{P}$ are, therefore, really low and are estimated in the model to be 2.0 and $0.5 \mathrm{mg} / \mathrm{kg}$ of BW, respectively (Vipperman et al., 1974).

\section{Parameterization and Model Evaluation}

The model was built with a mechanistic approach in which the underlying mechanisms leading to $\mathrm{P}$ and $\mathrm{Ca}$ utilization were represented. Parameter values were taken from experimental data on growing pigs. The model structure and its mathematical and logical consistencies and stability were checked throughout its development.

Literature data investigating $\mathrm{Ca}$ and $\mathrm{P}$ balances through total collection of feces and urine have been used for model evaluation. The database contained 21 experiments and 105 treatments collected from 20 scientific publications. A second database compiling $\mathrm{P}$ and $\mathrm{Ca}$ total body composition data using comparative slaughter techniques in growing pigs was also used for model evaluation. Only publications with complete description of the diets were included in this database.
This second database contained 80 treatments from 16 experiments in 5 published references (Rymarz et al., 1982; Hendriks and Moughan, 1993; Jondreville et al., 2004; Pomar et al., 2006; Rousseau, 2013).

The model was evaluated against its objectives of integrating the main physiological processes involved in $\mathrm{Ca}$ and $\mathrm{P}$ absorption and retention, with the most important modulating factors taken into account. The originality of this model lies in the dissociation between the soft and bone masses and growth. The most relevant model mechanisms and outputs were evaluated by simulating experimental situations and comparing the predictions of the model to observed data or assumptions.

Model evaluation was performed in 3 steps in a reference production situation in which a pig at $50 \mathrm{~kg} \mathrm{BW}$ was fed a corn and soybean meal-based diet that fulfilled the digestible $\mathrm{P}$ and total Ca requirements (NRC, 2012). Phosphorus retention in bone (PBn retention) and $\mathrm{P}$ retention in soft tissue (P in soft tissue [PSt] retention) were the main performance parameters used in this analysis. The first step consisted of a conventional univariate sensitivity analysis performed by iteratively varying the major model parameters means from -1.5 to +1.5 times their respective SD reported in literature while keeping all other variables at their central value. The objective of this sensitivity analysis was to identify critical areas in the system and highlight the most influential factors implicated in $\mathrm{Ca}$ and $\mathrm{P}$ metabolism. Univariate sensitivity indexes expressed relative to the reference situation values made it possible to evaluate the relative magnitude of the deviations. Model parameter interactions were not investigated in this analysis.

In the second step, general model behavior was studied by simulating specific dietary situations with the objective of evaluating the ability of the model to adequately represent critical aspects of $\mathrm{P}$ and $\mathrm{Ca}$ metabolism. The results of these simulations are the logical consequences and mathematical representations of the hypotheses included in the model. Then, to ensure that model's daily outputs were in the range of the responses reported in the literature, the 2 databases described above were used in a third step for model evaluation analysis to simulate the $\mathrm{Ca}, \mathrm{P}$, protein, and ash whole body composition with inputs from experimental diets and the $\mathrm{Ca}$ and $\mathrm{P}$ digestibility and retention coefficients derived from balance studies. The simulation results were used to compare predicted and observed values.

As direct comparisons between model simulations and experimental outputs are often considered to be irrelevant, because the interexperiment variability is much greater than the within-experiment variability (Sauvant et al., 2005), the random effect of the experiment was included in the statistical model to compare observed and predicted values using the MIXED procedure of the 
SAS software program (SAS Inst. Inc., Cary, NC). The ability of the proposed simulation model to reproduce experimental conditions was evaluated based on the statistical properties of the intercept, the slope, and $R^{2}$ obtained between observed and predicted values. The mean square prediction error (MSPE) was broken down into error in central tendency (ECT), error due to regression (ER), and error due to disturbance (ED), as suggested by Pomar and Marcoux (2005), Theil (1966), and Bibby and Toutenburg (1977). The ECT indicates the extent to which the average of the predicted dependent variables deviates from the average of the observed values. The ER measures the deviation of the least squares regression coefficient from 1 , the value obtained if observed and simulated results were in complete agreement. The ED is the variation in the observed values that is not accounted for by a least squares regression of observed on predicted values. This error is, in fact, the unexplained variance and represents the portion of MSPE that cannot be eliminated by linear transformation (Theil, 1966). Additionally, relative MSPE (rMSPE) expressed as a percentage of the observed mean was also used as a measure of the prediction error.

\section{RESULTS AND DISCUSSION}

\section{Sensitivity Analysis}

Varying the major model parameters from -1.5 to 1.5 times their SD generated small changes in terms of P deposition into bone and soft tissue. Changes in ATTD of phytate $\mathrm{P}(2.3 \mathrm{~g} / \mathrm{kg}$ diet $)$ from 0.11 to 0.41 and dicalcium phosphate $(1.74 \mathrm{~g} / \mathrm{kg}$ diet) from 0.58 to 0.98 induced the greatest variation in $\mathrm{PBn}$ retention $(-6$ to $+1 \%$ and -3 to $+1 \%$, respectively). The response of $\mathrm{PBn}$ retention to increasing P digestibility is not linear and NRC (2012) $\mathrm{P}$ requirement provides $85 \%$ of the amount needed for maximal $\mathrm{Bn}$ mineralization. This is due to the fact that they lowered the $\mathrm{Ca}$ requirement to a ratio of 2.15 $\mathrm{Ca}$ :digestible $\mathrm{P}$ and, therefore, dietary $\mathrm{Ca}$ limits the $\mathrm{P}$ deposition into bone in the simulation. Varying fecal EPL (from 0 to $380 \mathrm{mg} / \mathrm{kg}$ DMI) also slightly modified PBn retention ( -2 to $+1 \%)$, indicating that gastrointestinal endogenous $\mathrm{P}$ secretions were not important determinants of total $\mathrm{P}$ requirement and homeostasis. Ajakaiye et al. (2003) and Shen et al. (2002) reported greater values (450 and $670 \mathrm{mg} / \mathrm{kg}$ DMI) than those that had previously been reported (100 to $200 \mathrm{mg} / \mathrm{kg}$ DMI). Nevertheless, if these losses were greater than the simulated ones, the model will be able to take their impact into account. The sensitivity of PBn retention to P ATTD and endogenous losses indicates that even if pigs were fed to requirements, $\mathrm{P}$ absorption was not saturated. This finding is consistent with the fact that the digestible $\mathrm{P}$ requirement set by the
NRC (2012) is 0.85 of maximum P retention. Given that the model gives priority to PSt retention over PBn retention, ATTD coefficients and fecal EPL had no impact on PSt retention. Digestibility coefficients and EPL were considered to be hard data or statements with adequate proof (Whittemore, 1983) in the model, as numerous publications were available on this topic.

Decreasing the precocity value parameter of the Gompertz function decreases protein retention and thus PSt retention ( $-16 \%$ at $-1.5 \mathrm{SD})$ and increases PBn retention only slightly ( $1 \%$ at $-1.5 \mathrm{SD})$. Similarly, modifying $\mathrm{P}$ concentration in subcutaneous fat reduced PSt retention but to a lower extent $(-2 \%)$, given that the $\mathrm{P}$ found in soft tissue is mainly in the protein compartment. The concentrations of $\mathrm{P}$ in body proteins and lipids are difficult to estimate from the literature data, given that only 1 study (Nielsen, 1973) was available; those concentrations can, therefore, be considered to be soft data or statements with inadequate, but some, proof. The Gompertz function was adjusted to fit the protein deposition of modern pigs as estimated from numerous dual-energy X-ray absorptiometry (unpublished data) and is, therefore, considered hard data.

\section{Model Behavior}

Body Partitioning in Adequate and Low-Lysine Diets. A simulation of a reference $50 \mathrm{~kg}$ pig fed at requirements (NRC, 2012) or given a low-Lys $\operatorname{diet}(-40 \%$ Lys) was performed. In the reference pig, about $99 \%$ of dietary $\mathrm{Ca}$ and 60 to $70 \%$ of body $\mathrm{P}$ were deposited into bone in accordance with Crenshaw (2001; Fig. 3). It should be noted that in a diet formulated to maximize bone mineralization, which is not the case with the NRC (2012) reference pig, the proportion of $P$ will be close to $70 \%$. The remaining portion of available $\mathrm{P}$ was fixed in soft tissue with most of the $\mathrm{P}$ retained in the protein compartment, in agreement with Nielsen (1973). This result reflects the indispensable role that $P$ plays in muscle metabolism: energy (ATP), protein utilization during exercise (creatinine), cell membranes, and phosphoproteins (e.g., phosphatase, phosphorylase). Indeed, P deprivation is characterized by muscle weakness and creatinuria (Schneider and Steenbock, 1939). Reducing dietary Lys by $40 \%$ in pigs fed according to the requirements set by the NRC (2012) reduced protein deposition and in turn the amount of $\mathrm{P}$ deposited into protein compartment by $14 \%$ (Fig. 3). This simulation illustrates the importance of the protein pool in P metabolism. As expected, protein deficiency slightly increased lipid deposition but not enough to increase $\mathrm{P}$ deposition in lipid, given that the low concentration of $\mathrm{P}$ in lipid tissues was unaffected by dietary Lys. Given that bone mineralization potential was not obtained in 
a pig fed to the P requirement set by the NRC (2012), the $\mathrm{P}$ that is normally prioritized to soft tissue was deposited into bone $(+7 \%)$ because of the reduced protein retention induced by the low-Lys diet. Such priority for soft tissue over bone indicates that the PBn minerals provide a reserve supply whereas the PSt plays vital functional roles that are protected (Day and McCollum, 1939). Similar results were obtained for body Ca but are quantitatively less important, given the low proportion of body $\mathrm{Ca}$ found in protein. This partitioning of the available $\mathrm{P}$ between bone and soft tissue is in accordance with studies in which pigs fed low-CP and low-P diets had greater bone ash, $\mathrm{P}$, and $\mathrm{Ca}$ concentrations in bone than pigs fed high-CP and low-P diets (Reinhard et al., 1976; Varley et al., 2011b). Varley et al. (2011b) speculated that the bone ash decrease observed in pigs fed high-CP diets resulted from the catabolism of dietary $\mathrm{CP}$, which generated metabolic acids leading to excess acidity that was buffered by alkaline mineral reserves in bone (Arnett, 2007). However, many studies showed a positive influence of high-protein diets on bone health in humans (Conigrave et al., 2008). A better understanding of the complex interactions between the dietary acid-base balance, $\mathrm{Ca}$ and $\mathrm{P}$ metabolism, and bone growth is needed before this modulating factor can be introduced into the model.

Simulation of Dietary Phosphorus and Calcium Imbalance. The impact of imbalances were tested by simulating the impact of increasing calcium carbonate in a diet that fulfilled dietary P requirements (NRC, 2012) and increasing dicalcium phosphate in a diet that fulfilled Ca requirements (NRC, 2012). Increasing calcium carbonate in a Ca-deficient diet resulted in a concomitant increase in $\mathrm{PBn}$ and $\mathrm{CaBn}$ retention, whereas the retention of $\mathrm{P}$ and $\mathrm{Ca}$ in soft tissue did not change, in agreement with the model's hypothesis. These results were accompanied by a reduction in $\mathrm{P}$ urinary excretion to the minimum level whereas that of $\mathrm{Ca}$ increased when maximum retention in bone was reached (Fig. $4 \mathrm{a}$ and $4 \mathrm{~b}$ ), as previously shown by Pointillart and Fontaine (1983) and Létourneau-Montminy et al. (2011). This finding is in accordance with number of studies showing hyperphosphaturia during Ca imbalance (Vipperman et al., 1974; Létourneau-Montminy et al., 2011).

Similarly, in a P-deficient diet, where the lack of $\mathrm{P}$ meant that none of the ingested $\mathrm{Ca}$ could be utilized, absorbed $\mathrm{Ca}$ had to be excreted. Therefore, increasing dietary phosphate in a P-deficient and nonlimiting-Ca diet resulted in similar concomitant increases in $\mathrm{PBn}$ and $\mathrm{CaBn}$, no effect on retention in soft tissue, a decrease in the urinary excretion of $\mathrm{Ca}$, and an increase in P urinary losses (Fig. $4 \mathrm{c}$ and $4 \mathrm{~d}$ ). These responses to dietary $\mathrm{P}$ imbalance are in agreement with the literature data (Vipperman et al., 1974; Pointillart et al., 1987).
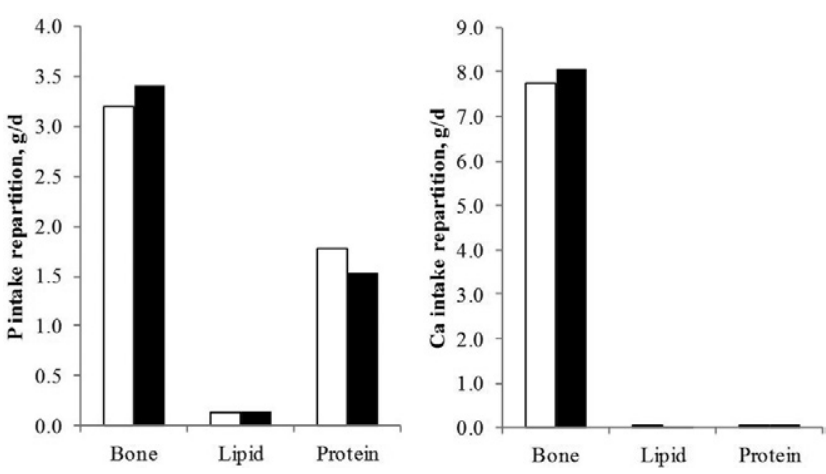

Figure 3. Phosphorus and calcium intake and body partitioning in pigs fed a normal diet (white columns) or a low-Lys diet (black columns).

Simulation of Dietary Phosphorus and Calcium Depletion and Repletion Sequences. The results of the simulation of Létourneau-Montminy et al. (2014) data, which depleted pigs $(60 \%$ of the digestible and total $\mathrm{Ca}$ in the control diet) for $28 \mathrm{~d}$ and then repleated with a control diet that fulfilled requirements for an additional $28 \mathrm{~d}$, indicated a remaining deficit of $8 \%$ in the model in comparison with $9 \%$ in the experiment. The results of the study by Gonzalo et al. (2014) study conducted with a similar depletion-repletion experimental design showed a remaining $\mathrm{CaBn}$ deficit of $12 \%$ in comparison with $8 \%$ in the simulation. Adaptation to low-nutrient diets has long been recognized. Experimental Ca depletion-repletion studies in several species, including rats (Stauffer et al., 1972; Drivdahl et al., 1984), humans (Akesson et al., 1998), and pigs (Fammatre et al., 1977; Ryan et al., 2011; Létourneau-Montminy et al., 2014), have shown that bone tissue presents mechanisms that allow replenishment of losses that result from the mobilization of bone mineral reserves during $\mathrm{Ca}$ and $\mathrm{P}$ deficiency. In pigs and broiler chickens, this compensatory bone mineralization came from both an increase of $\mathrm{Ca}$ and $\mathrm{P}$ intestinal absorption and bone retention (Ashwell, 2009; LétourneauMontminy et al., 2014). The mechanisms implicated during depletion and repletion are complex and involve at least 2 hormones, namely parathyroid hormone and calcitriol, that act on intestinal absorption, renal reabsorption, and bone formation and resorption (Parfitt, 1976). Moreover, bones apparently respond differently to $\mathrm{Ca}$ or P deficiency (Aiyangar et al., 2010; Gonzalo et al., 2014).

\section{Comparison between Predicted and Observed Whole- Body Phosphorus, Calcium, Ash, and Protein Accretion}

Model simulations results were compared with literature data to investigate the effect of sex, and dietary $\mathrm{Ca}$ and $\mathrm{P}$ dietary concentrations on body mineral composition as reported in studies comparative slaughter techniques. The random effect of experiment was never significant, probably owing to the small number of ex- 
a

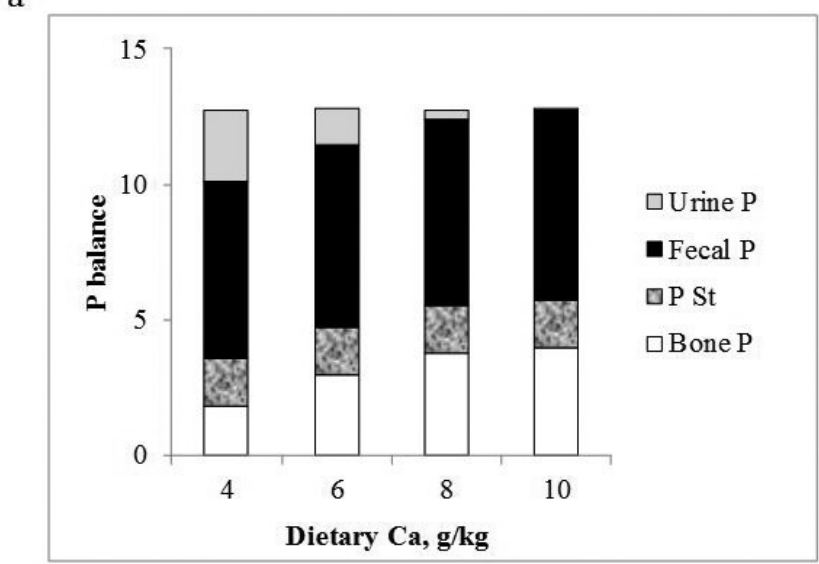

c

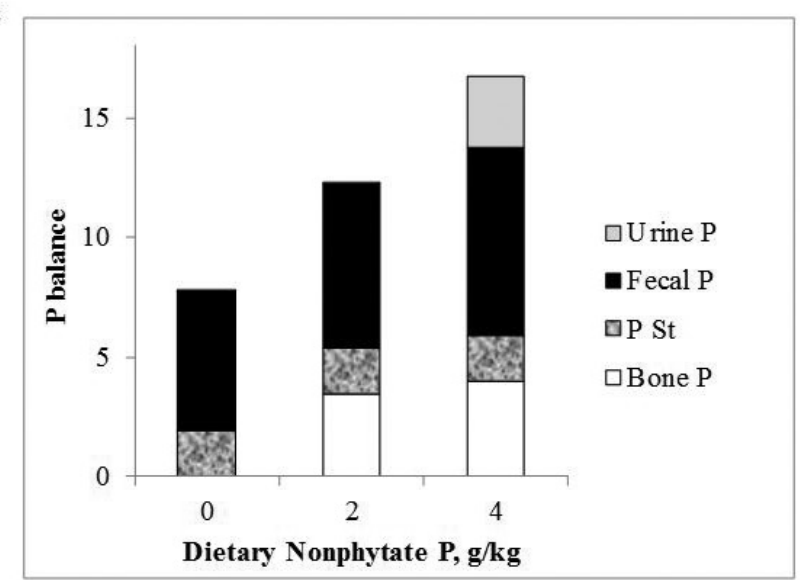

b

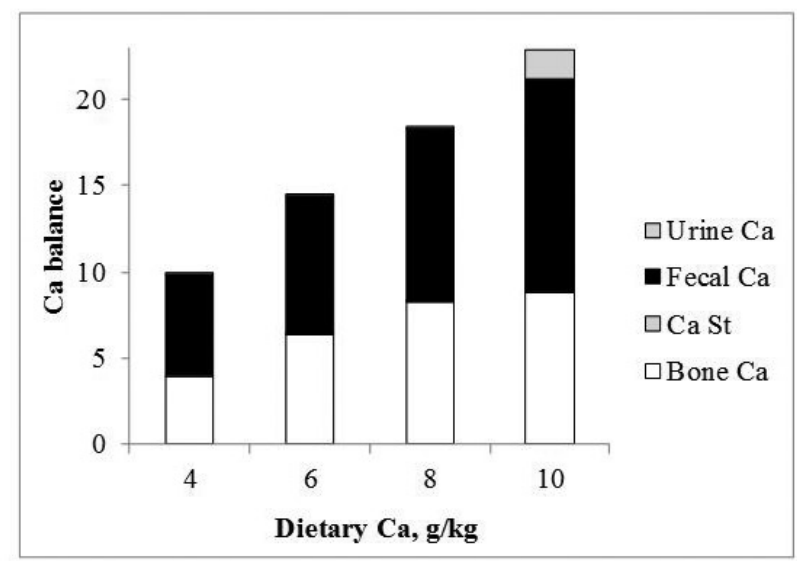

d

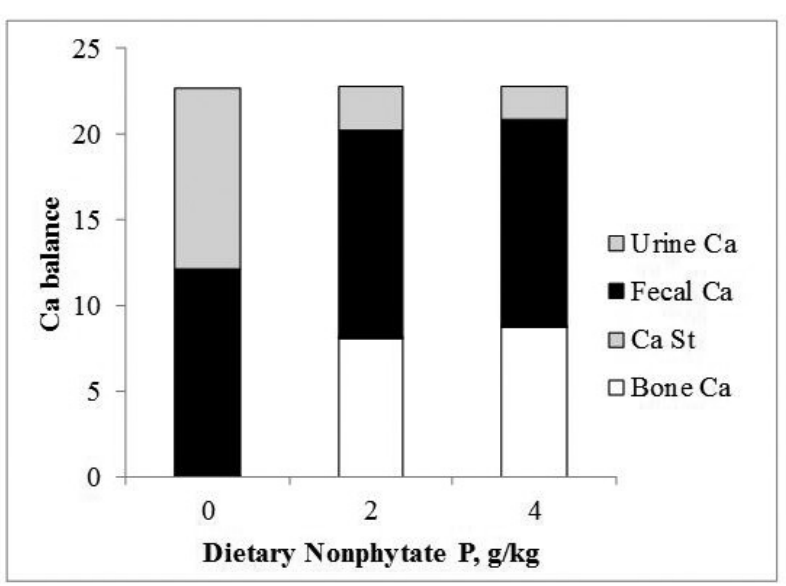

Figure 4. Response of increasing dietary calcium in a diet adequate in phosphorus and deficient in dietary calcium on phosphorus (a) and calcium (b) balance and of increasing dietary dicalcium phosphate in a diet adequate in calcium and deficient in dietary phosphorus on phosphorus (c) and calcium (d) balance. $\mathrm{St}=$ soft tissue

periments. Mean deviation from the bisector indicated that body protein and ash were slightly (less than $-2 \%$ ) underpredicted by the model, whereas body $\mathrm{Ca}$ and $\mathrm{P}$ were slightly overpredicted (1\%; Fig. 5). All body components were predicted with adequate accuracy as intercepts and slopes did not deviate from 0 and 1 in any case. For body protein, rMSPE was low $(3.7 \%)$ and associated mainly with ED (83\%); the remainder was $8 \%$ ECT and 9\% ER. The model was calibrated to represent each experiment's protein dynamics. The Gompertz function adequately represented the observed trends. Regarding body $\mathrm{Ca}$, the rMSPE was greater for protein (9.1\%) but again mainly related to ED (97\%). Owing to a lack of data on bone growth potential, $\mathrm{Ca}$ deposition potential was linked to protein deposition potential in the model. However, it is generally accepted that bone tissue accretion in pigs initially develops faster than muscle tissue and then declines, whereas muscle tissue accretion continues to increase (Mahan, 1978). The fact that the model accurately predicted whole-body protein and $\mathrm{Ca}$ depositions confirmed that the growth of bone and muscle in modern pigs is similar, probably owing to continued selection efforts for improved growth and leaner carcasses. The rMSPE for body $\mathrm{P}$ was $8.8 \%$ and about $1 \%$ of the error was ECT and $2 \%$ was ER. Given the prediction accuracy for whole-body $\mathrm{Ca}$ and the fact that body $\mathrm{P}$ found in bone is deposited in a fixed ratio with $\mathrm{Ca}$, whole-body $\mathrm{PBn}$ deposition can be considered to be as accurate as $\mathrm{CaBn}$. Therefore, the increased ER for $\mathrm{P}$ compared with that for $\mathrm{Ca}$ was probably the result of a small underestimation of PSt retention and thus the amount of $\mathrm{P}$ deposited into protein compartment, which is quantitatively larger.

Although errors for both $\mathrm{Ca}$ and $\mathrm{P}$ were low and mainly random in nature (ED), it can be seen that 4 points reporting the body composition of pigs at $120 \mathrm{~kg}$ BW from the same study (Jondreville et al., 2004) were underestimated (Fig. 5). A similar trend was observed for $\mathrm{Ca}$ and $\mathrm{P}$, but the underestimation was related to bone deposition. However, body protein was not available in that paper, and therefore, the body Ca:protein ratio was an unknown input; the default value of 0.05 had to be and could be responsible for these discrepancies. Finally, as the proposed model calculates ash from body $\mathrm{P}$ and $\mathrm{Ca}$, ash followed a trend similar to body $\mathrm{Ca}$ and $\mathrm{P}$, with $8.5 \%$ rMSPE, 94\% ED, and 6\% ECT. 
a
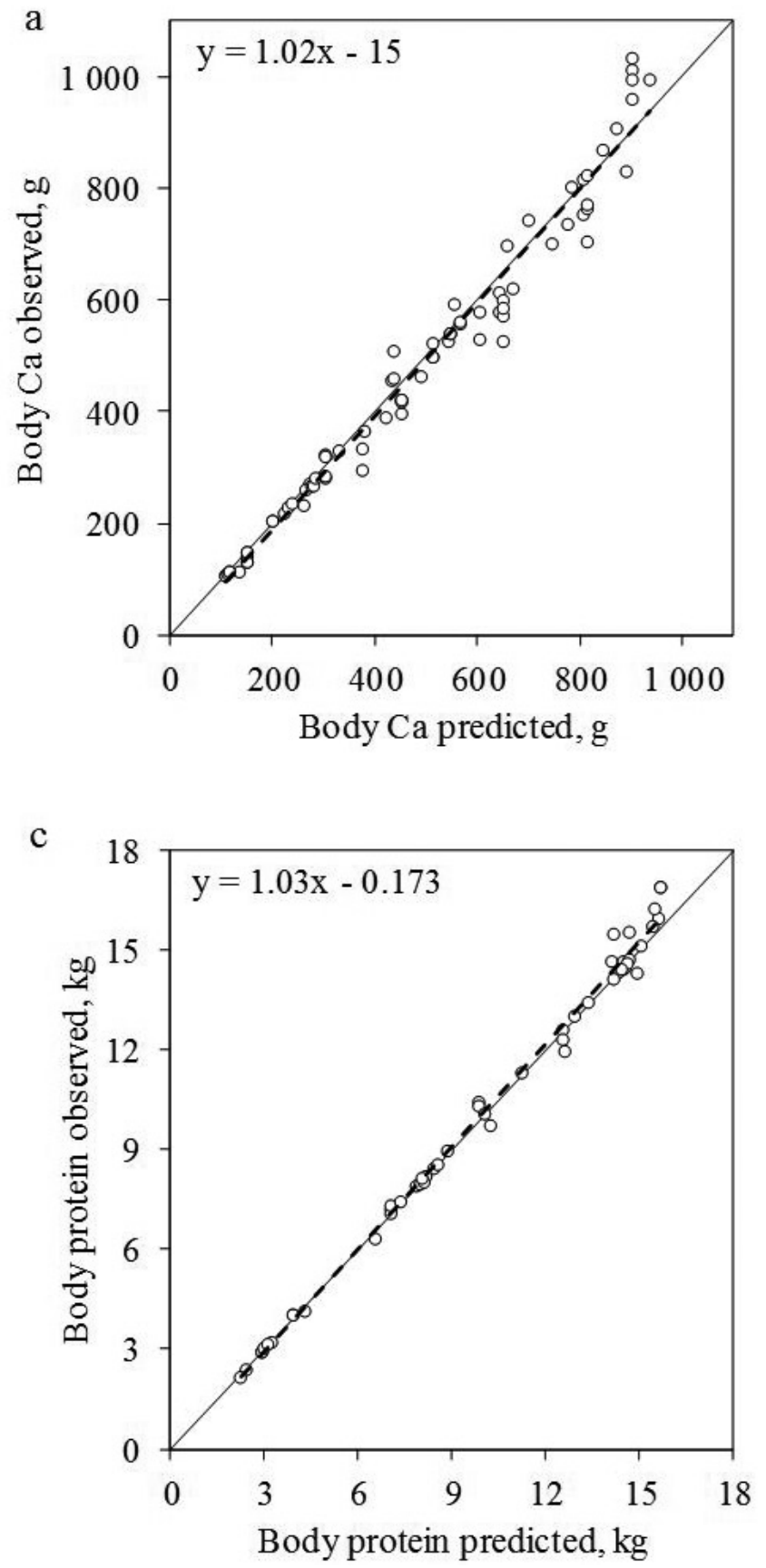

$\mathrm{b}$

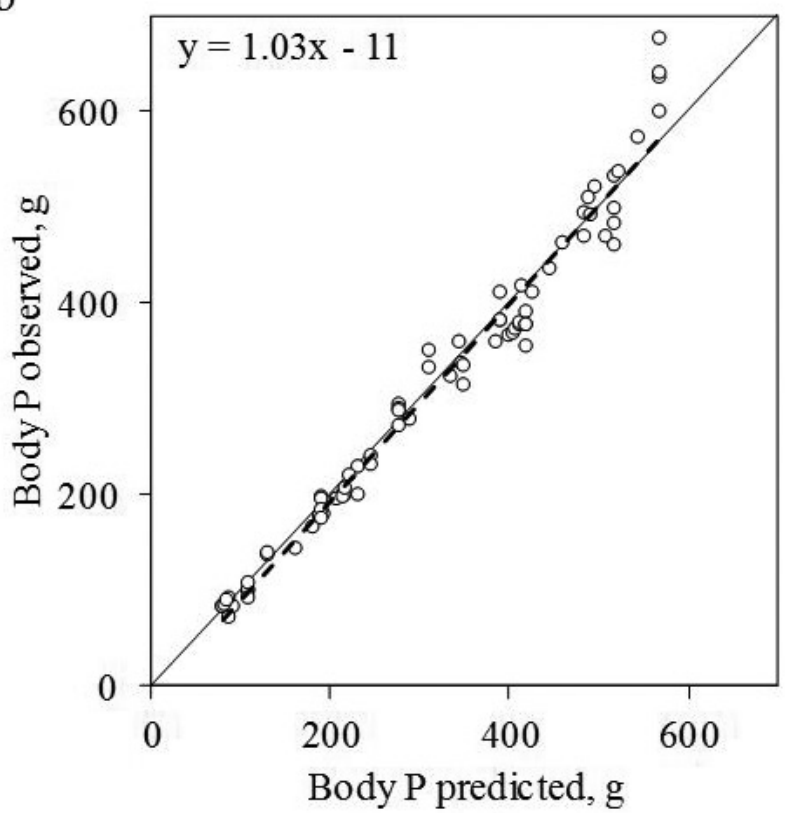

d

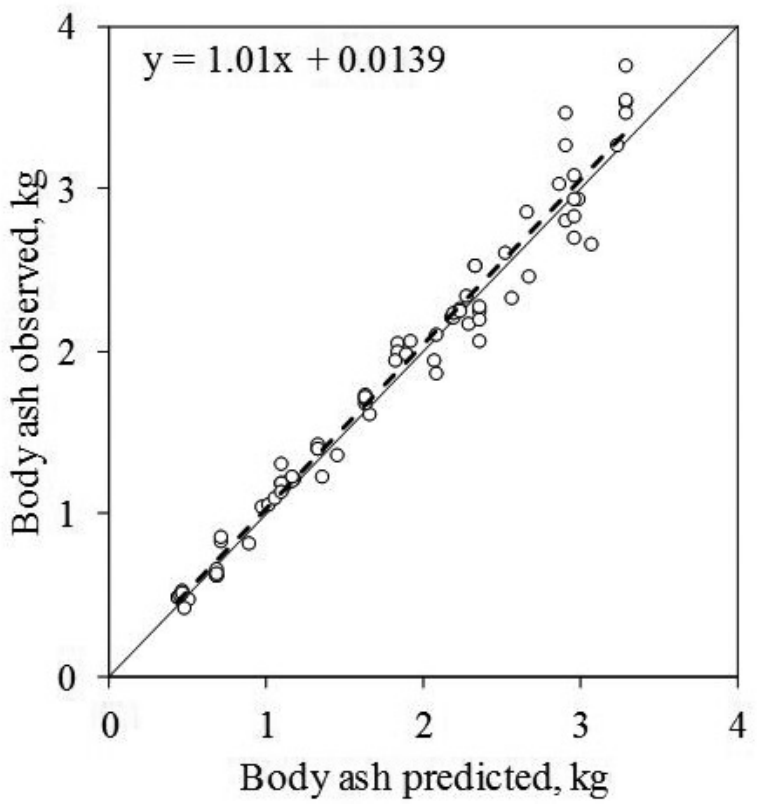

Figure 5. The relationship between observed and predicted body composition in calcium (a; no. of observations [Nobs] $=76$, relative mean square prediction error $[\mathrm{rMSPE}]=9.08 \%$, error in central tendency $[\mathrm{ECT}]=2.3 \%$, error due to regression $[\mathrm{ER}]=1.1 \%$, and error due to disturbance $[\mathrm{ED}]=$ $96.6 \%$ ), phosphorus $(\mathrm{b} ; \mathrm{Nobs}=76, \mathrm{rMSPE}=8.8 \%, \mathrm{ECT}=1.1 \%, \mathrm{ER}=2.4 \%$, and $\mathrm{ED}=96.5 \%)$, ash $(\mathrm{c} ; \mathrm{Nobs}=76, \mathrm{rMSPE}=8.5 \%, \mathrm{ECT}=5.7 \%, \mathrm{ER}=$ $0.5 \%$, and $\mathrm{ED}=93.8 \%$ ), and protein $(\mathrm{d}$; Nobs $=52$, rMSPE $=3.4 \%, \mathrm{ECT}=8.3 \%, \mathrm{ER}=8.6 \%$, and $\mathrm{ED}=83.1 \%) . \mathrm{x}=\mathrm{y}$ line $(-)$ and regression line $(--)$.

The actual $\mathrm{CaBn}$ and $\mathrm{PBn}$ deposition depends on the availability of the absorbed $\mathrm{Ca}$ and $\mathrm{P}$ and the balance between them. Therefore, soft tissue and bone mineral growth are linked only when animal are fed to maximize both soft tissue and bone growth. The studies by Pomar et al. (2006) and Rousseau (2013), in which dietary $\mathrm{Ca}, \mathrm{P}$, and microbial phytase have varied, that were used to further evaluate the model showed that whole-body $\mathrm{P}$ and $\mathrm{Ca}$ can be decreased without protein deposition being modified. For example, Pomar et al.
(2006) showed that body $\mathrm{P}$ was decreased by $48 \%$ and body protein by $1 \%$ if dietary digestible $\mathrm{P}$ and $\mathrm{Ca}$ was reduced by $50 \%$. In such situations, the model predicts decreases of $51 \%$ in body $\mathrm{P}$ and $5 \%$ in body protein. Similarly, Rousseau (2013) reported that body P was increased by $18 \%$ and body protein was increased by $10 \%$ in pigs fed a diet supplemented with 700 phytase units $/ \mathrm{kg}$ of microbial phytase, whereas the model's predictions are 19 and $9 \%$, respectively. The model is, therefore, able to independently simulate bone and soft 
tissue growth. The adequate and unbiased prediction of whole-body protein, $\mathrm{Ca}$, and $\mathrm{P}$ deposition support that the main modulating factors implicated in $\mathrm{P}$ and $\mathrm{Ca}$ metabolism are accommodated by the proposed model.

\section{Comparison between Predicted and Observed Apparent Total Tract Digestibility and Retention Coefficients of Calcium and Phosphorus}

The model simulations were compared with literature data investigating $\mathrm{Ca}$ and $\mathrm{P}$ balance data based on total collection of feces and urine. The P ATTD was predicted with good adequacy, as the intercept and slope did not differ from 0 and 1 , respectively. However, for the $\mathrm{P}$ retention coefficient, the slope differed from unity (1.15; $P<0.05$; Fig. 6). The rMSPE was about $15 \%$ for the P ATTD and retention coefficient. The errors were mostly ED (90 and $88 \%$, respectively) and the remaining errors are ECT ( 9 and 7\%, respectively). Although low, such errors indicate a systematic underestimation of P ATTD that is then reflected in the P retention coefficient. This underestimation may be the result of the fecal EPL used in the model, which was $0.139 \mathrm{~g} / \mathrm{kg}$ DMI was according to Petersen and Stein (2006). Indeed, these losses correspond to $7.8 \mathrm{mg} / \mathrm{kg}$ $\mathrm{BW}$ for a $25-\mathrm{kg}$ pig (the average $\mathrm{BW}$ of the data that were simulated); that value was higher than the basal losses ( $3 \mathrm{mg} / \mathrm{kg} \mathrm{BW}$ ) estimated by previous authors (Jongbloed and Everts, 1992; Dilger and Adeola, 2006; Pettey et al., 2006). The data used to validate the model were based on results that were deficient in P. Such deficiencies were accompanied by basal fecal EPL and larger P ATTD through regulatory processes that are not yet included in the model (Jongbloed and Everts, 1992; Létourneau-Montminy et al., 2014). Finally, the low ER showed that representing $\mathrm{P}$ absorption with a linear equation was accurate. Therefore, passive diffusion was more important than active transport at high levels of P (Jongbloed and Mroz, 1997; Stein et al., 2008).

The rMSPE for Ca ATTD is $11 \%$, and $88 \%$ of the error is from ED and is, therefore, not accounted for by the least square regression of observed on predicted values. The $R^{2}$ is, however, low (0.27), indicating a large variation in observed and predicted values. Information about $\mathrm{Ca}$ digestibility and modulating factors is scarce, and these results confirmed that other dietary or metabolic factors must be included. Finally, for the Ca retention coefficient, there was a large ER (49\%) followed by ED (28\%) and by ECT (23\%). The underprediction of ECT is due mostly to data in which P ATTD was underpredicted, which induced a lower $\mathrm{Ca}$ retention by the model. Indeed, when these data are corrected, the ECT was reduced to $11 \%$ (results not shown). Most of the error was ER, which comes from points with low
Ca retention values (Fig. 6). These data were characterized by pigs fed a P-deficient diet with marked hypercalciuria. In the model, $\mathrm{Ca}$ can be retained only if there is sufficient P. However, in some studies where P was low (without supplemental phosphate), Ca was retained (e.g., Vipperman et al., 1974). Hypercalciuria is the most consistent metabolic abnormality found in patients with calcium nephrolithiasis (Bushinsky et al., 1995). In pigs fed normal-Ca vs. high-Ca diets $(+55 \%)$ with normal P, Pointillart et al. (1987) observed an increased in the Ca content of the kidney. In the present study, when the hypercalciuria treatments were removed from the database, the ER was reduced to $11 \%$ (results not shown). A better understanding of $\mathrm{Ca}$ and $\mathrm{P}$ metabolism in an acute deficiency is needed. The regulation of $\mathrm{Ca}$ and $\mathrm{P}$ absorption is not yet included in the model. As a result, fecal $\mathrm{Ca}$ excretion may be overpredicted and urinary $\mathrm{Ca}$ excretion may be underestimated in diets that are extremely deficient in P. In contrast, P fecal excretion can be overestimated leading to lower Ca retention.

\section{Impact of Dietary Calcium and Phosphorus on Growth Performance}

In the InraPorc growth model (van Milgen et al., 2008), growth performance is driven by NE and essential AA supply. Phosphorus deficiency also has been reported to modify growth performance through a loss of appetite and reduced growth (Suttle, 2010). In fact, pigs fed with low-P diets frequently have low growth rate, feed intake, and feed efficiency. Increasing available $\mathrm{P}$ in these low-P diets increases both feed intake and growth rates, but feed intake reaches normal values before growth rate (Reinhart and Mahan, 1986; LétourneauMontminy and Narcy, 2013); this suggesting that different mechanisms are implicated in these animal responses to dietary P deprivation (Underwood and Suttle, 1999). Additionally, high dietary $\mathrm{Ca}$ is known to aggravate symptoms of $\mathrm{P}$ deficiency (Létourneau-Montminy et al., 2012, Létourneau-Montminy and Narcy, 2013) through a reduced absorption due to the formation of insoluble Ca-P complexes (Narcy et al., 2012; Heaney and Nordin, 2002). The mechanisms implicated in the animal responses to $\mathrm{Ca}$ and $\mathrm{P}$ deficiencies are not well known, and therefore, the impact of these mineral deficiencies on feed intake and growth performance have not been included in the proposed model.

\section{Conclusions and Outlooks}

Although vital for the animal, $\mathrm{P}$ has to be finely managed to allow the animal to express its full production potential while minimizing $\mathrm{P}$ excretion, thus avoiding its detrimental environmental effect. Phosphorus 
a

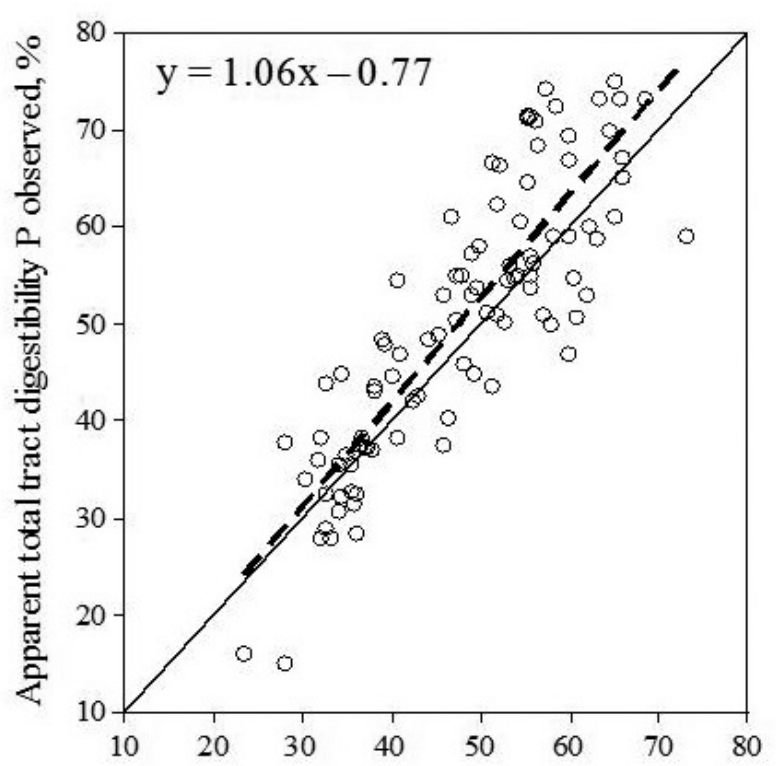

Apparent total tract digestibility P predicted, \%

c

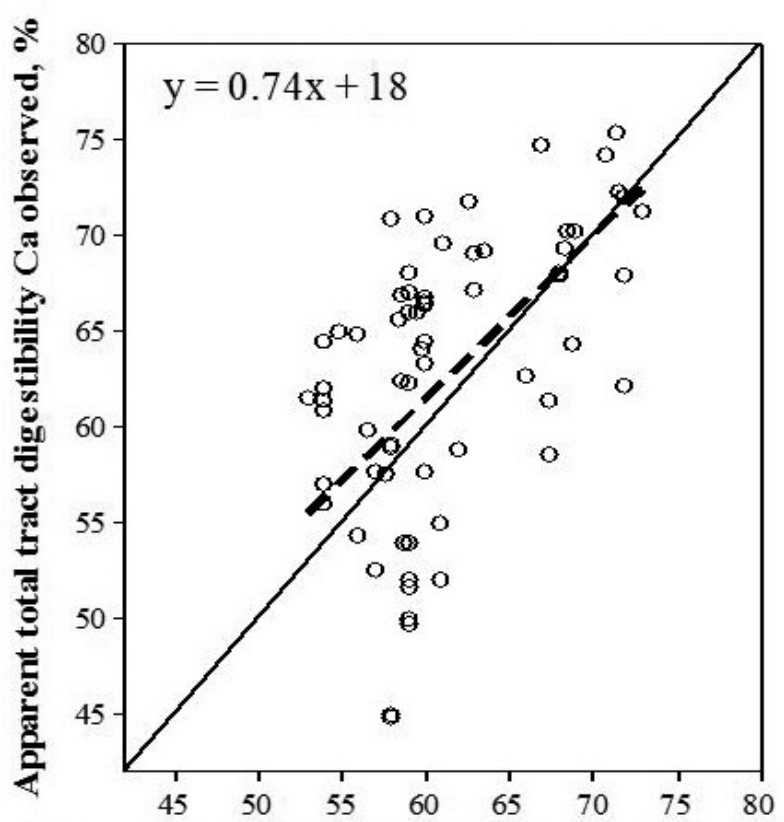

Apparent total tract diges tibility $\mathrm{C}$ a predicted, \% $\mathrm{b}$

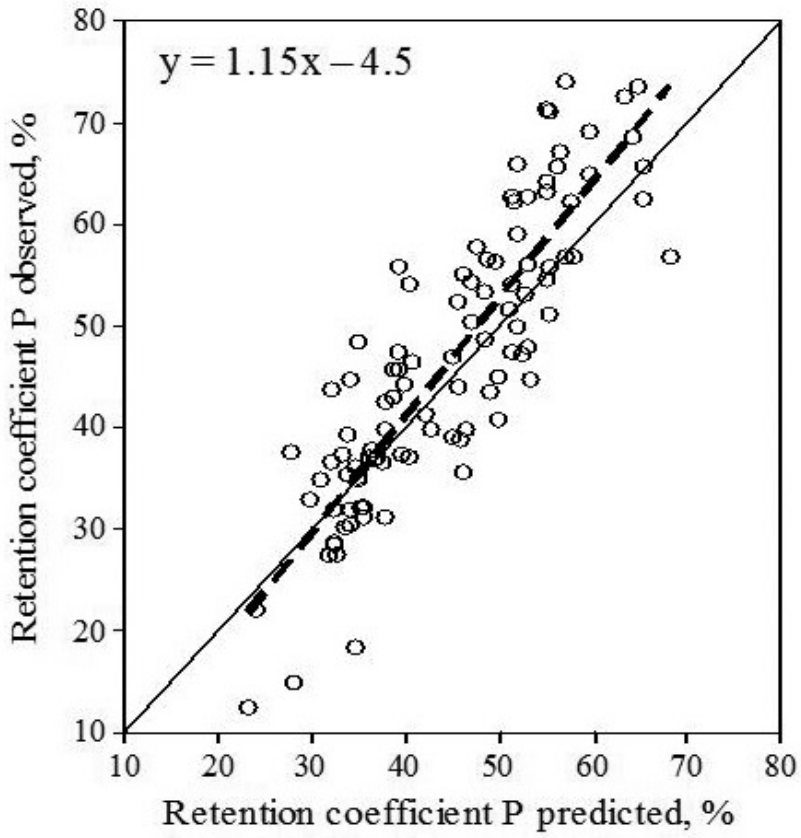

d

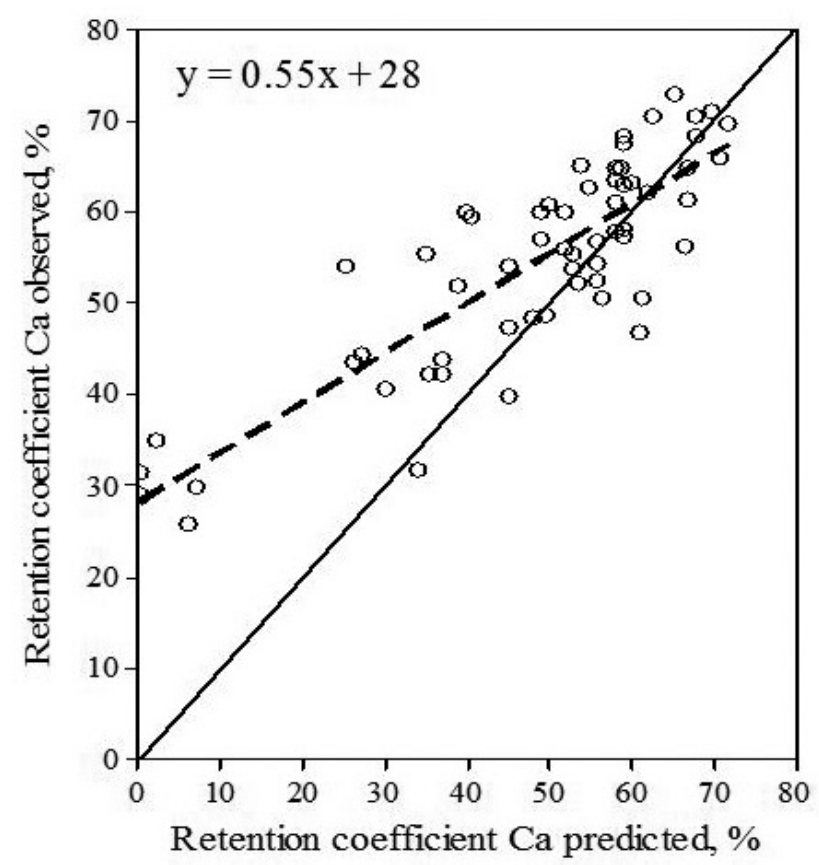

Figure 6. The relationship between observed adjusted for experiment effect and predicted apparent total tract digestibility in phosphorus (a; no. of observations $[\mathrm{Nobs}]=95$, relative mean square prediction error $[\mathrm{rMSPE}]=15.0 \%$, error in central tendency $[\mathrm{ECT}]=9.3 \%$, error due to regression $[\mathrm{ER}]=$ $0.94 \%$, and error due to disturbance $[\mathrm{ED}]=89.7 \%$ ), phosphorus retention coefficient $(\mathrm{b} ; \mathrm{Nobs}=95, \mathrm{rMSPE}=15.5 \%, \mathrm{ECT}=7.4 \%, \mathrm{ER}=4.6 \%$, and $\mathrm{ED}=$ $88.0 \%$ ), apparent total tract digestibility in calcium ( $\mathrm{c}$; Nobs $=63$, $\mathrm{rMSPE}=11.1 \%, \mathrm{ECT}=8.1 \%, \mathrm{ER}=3.9 \%$, and $\mathrm{ED}=88.0 \%$ ), and calcium retention coefficient ( $\mathrm{d}$; Nobs $=63, \mathrm{rMSPE}=21.2 \%, \mathrm{ECT}=22.6 \%, \mathrm{ER}=49.0 \%$, and $\mathrm{ED}=28.4 \%) . \mathrm{x}=\mathrm{y}$ line $(-)$ and regression line (--). Data from Almeida and Stein (2010), Düngelhoef et al. (1994), Hill et al. (2009), Ketaren et al. (1993), Lantzsch et al. (1995), Larsen and Sandström (1993), Létourneau-Montminy et al. (2010), Lyberg et al. (2005), Murry (1995), Narcy et al. (2010), Pallauf et al. (1994), Pomar et al. (2006), Rodehutscord et al. (1999), Spencer et al. (2000), Stein et al. (2008, 2011), Veum et al. (2001), Vipperman et al. (1974), and Zimmermann et al. (2002, 2003).

metabolism is complex and its quantification difficult, partially because of its strong link with $\mathrm{Ca}$. A mechanistic mathematical model is proposed to represent the factors that quantitatively have a major impact in the determination of animal responses while ensuring flexibility and allow effective prediction in a wide range of production situations. Because $\mathrm{Ca}$ and $\mathrm{P}$ metabolism and soft tissue growth main factors are represented into 
the proposed model, $\mathrm{Ca}$ and $\mathrm{P}$ requirements can be estimated based on the desired production objectives, such as maximizing growth performance, bone mineralization, or minimizing $\mathrm{P}$ excretion. It has been demonstrated that the proposed model accurately simulates whole body $\mathrm{P}, \mathrm{Ca}$, protein, and lipid as well as $\mathrm{P}$ digestibility and retention. However, the prediction accuracy is lower for Ca digestibility and retention, an area that deserves further research.

\section{LITERATURE CITED}

Aiyangar, A. K., A. G. Au, T. D. Crenshaw, and H. L. Ploeg. 2010. Recovery of bone strength in young pigs from an induced short-term dietary calcium deficit followed by a calcium replete diet. Med. Eng. Phys. 32:1116-1123. doi:10.1016/j. medengphy.2010.08.001.

Ajakaiye, A., M. Z. Fan, T. Archbold, R. R. Hacker, C. W. Fosberg, and J. P. Phillips. 2003. Determination of true digestive utilization of phosphorus and the endogenous phosphorus outputs associated with soybean meal for growing pigs. J. Anim. Sci. 81:2766-2775.

Akesson, A., R. Ekman, H. Prytz, and F. Sundler. 1998. Tissue concentrations of gastrointestinal regulatory peptides in the duodenal mucosa in systemic sclerosis. Clin. Exp. Rheumatol. 16:141-148.

Alexander, L. S., A. Qu, S. A. Cutler, A. Mahajan, S. R. Lonergan, M. F. Rothschild, T. E. Weber, B. J. Kerr, and T. H. Stahl. 2008. Response to dietary phosphorus deficiency is affected by genetic background in growing pigs. J. Anim. Sci. 86:2585-2595. doi:10.2527/jas.2007-0692.

Almeida, F. N., and H. H. Stein. 2010. Performance and phosphorus balance of pigs fed diets formulated on the basis of values for standardized total tract digestibility of phosphorus. J. Anim. Sci. 88:2968-2978. doi:10.2527/jas.2009-2285.

Arnett, T. R. 2007. Acid-base regulation of bone metabolism. Int. Cong. Series 1297:255-267.

Ashwell, C. M. 2009. Nutritional epigenetics: Early life conditioning with dietary phosphorus. In: 7th Annual Mid-Atlantic Nutrition Conference, University of Maryland, College Park. p. 180-191.

Bibby, J., and H. Toutenburg. 1977. Prediction and improved estimation in linear models. J. Wiley \& Sons, New York, NY.

Brautbar, N., D. N. B. Lee, J. W. Coburn, and C. R. Kleeman 1979. Normophosphatemic phosphate depletion in growing rat. Am. J. Physiol. 236:E283-E288.

Bronner, F., and W. D. Stein. 1995. Calcium homeostasis - An old problem revisited. J. Nutr. 125:1987S-1995S

Bushinsky, D. A., M. D. Grynpas, E. L. Nilsson, Y. Nakagawa, and F. L. Coe. 1995. Stone formation in genetic hypercalciuric rats. Kidney Int. 48:1705-1713. doi:10.1038/ki.1995.468

Charles, P. 1992. Calcium absorption and calcium bioavailability. J. Intern. Med. 231:161-168. doi:10.1111/j.1365-2796.1992. tb00519.x.

Cloutier, L., M. P. Létourneau-Montminy, J. F. Bernier, J. Pomar, and C. Pomar. 2014. Evaluation of a method estimating realtime individual lysine requirements in two lines of growing-finishing pigs. Animal 8:1-8. doi:10.1017/S1751731114003073.

Conigrave, A. D., E. M. Brown, and R. Rizzoli. 2008. Dietary protein and bone health: Roles of amino acid-sensing receptors in the control of calcium metabolism and bone homeostasis. Annu. Rev. Nutr. 28:131-155. doi:10.1146/annurev.nutr.28.061807.155328.

Crenshaw, T. D. 2001. Calcium, phosphorus, vitamin D, and vitamin $\mathrm{K}$ in swine nutrition. In: A. J. Lewis and L. L. Southern, editors, Swine nutrition. 2nd ed. CRC Press, Boca Raton, FL. p. 187-212.
Crenshaw, T. D., L. A. Rortvedt, and Z. Hassen. 2011. Triennial growth symposium: A novel pathway for vitamin D-mediated phosphate homeostasis: Implications for skeleton growth and mineralization. J. Anim. Sci. 89:1957-1964. doi:10.2527/jas.2010-3411.

Day, H. G., and E. V. McCollum. 1939. Mineral metabolism, growth, and symptomatology of rats on a diet extremely deficient in phosphorus. J. Biol. Chem. 130:269-283.

de Lange, C. F. M., C. H. Morel, and M. A. Birkett. 2003. Modeling chemical and physical body composition of the growing pig. J. Anim. Sci. 81:E159-E165.

Dilger, R. N., and O. Adeola. 2006. Estimation of true phosphorus digestibility and endogenous phosphorus loss in growing pigs fed conventional and low-phytate soybean meals. J. Anim. Sci. 84:627-634.

Drivdahl, R. H., C. C. Liu, and D. J. Baylink. 1984. Regulation of bone repletion in rats subjected to varying low-calcium stress. Am. J. Physiol. 246:R190-R196.

Düngelhoef, M., M. Rodehutscord, H. Spiekers, and E. Pfeffer. 1994. Effects of supplemental microbial phytase on availability of phosphorus contained in maize, wheat and triticale to pigs. Anim. Feed Sci. Technol. 49:1-10. doi:10.1016/0377-8401(94)90076-0.

Eklou-Kalonji, E., E. Zerath, C. Colin, C. Lacroix, S. Holy, I. Denis, and A. Pointillart. 1999. Calcium-regulating hormones, bone mineral content, breaking load and trabecular remodeling are altered in growing pigs fed calcium-deficient diets. J. Nutr. 129:188-193.

Fammatre, C. A., D. C. Mahan, A. W. Fetter, A. P. Grifo Jr., and J. K. Judy. 1977. Effects of dietary protein, calcium and phosphorus levels for growing and finishing swine. J. Anim. Sci. 44:65-71.

Fan, M. Z., and W. C. Sauer. 2002. Additivity of apparent ileal and fecal phosphorus digestibility values measured in single feed ingredients for growing-finishing pigs. Can. J. Anim. Sci. 82:183-191. doi:10.4141/A01-072.

Feaster, J. P., R. L. Shirley, C. J. Mc, and G. K. Davis. 1953. P32 distribution and excretion in rats fed vitamin D-free and low phosphorus diets. J. Nutr. 51:381-392.

Fox, J., D. W. Pickard, A. D. Care, and T. M. Murray. 1978. Effect of low phosphorus diets on intestinal calcium absorption and the concentration of calcium-binding protein in intact and parathyroidectomized pigs. J. Endocrinol. 78:379-387. doi:10.1677/joe.0.0780379.

González-Vega, J. C., C. L. Walk, Y. Liu, and H. H. Stein. 2013. Endogenous intestinal losses of calcium and true total tract digestibility of calcium in canola meal fed to growing pigs. J. Anim. Sci. 91:4807-4816. doi:10.2527/jas.2013-6410.

Gonzalo, E., M. P. Létourneau-Montminy, A. Narcy, J. F. Bernier, and C. Pomar. 2014. Optimisation des apports de phosphore et calcium pour maximiser leur utilisation chez le porc en croissance dans un contexte de durabilité. (In French.) Journ. Rech. Porcine Fr., [C. R.] 46(46):113-118.

Heaney, R. P., and B. E. Nordin. 2002. Calcium effects on phosphorus absorption: Implications for the prevention and cotherapy of osteoporosis. J. Am. Coll. Nutr. 21:239-244. doi:1 0.1080/07315724.2002.10719216.

Hendriks, D., and P. J. Moughan. 1993. Whole-body mineral composition of entire male and female pigs depositing protein at maximal rates. Livest. Prod. Sci. 33:161-170. doi:10.1016/0301-6226(93)90247-F.

Hill, B. E., A. L. Sutton, and B. T. Richert. 2009. Effects of lowphytic acid corn, low-phytic acid soybean meal, and phytase on nutrient digestibility and excretion in growing pigs. J. Anim. Sci. 87:1518-1527. doi:10.2527/jas.2008-1219. 
Hittmeier, L. J., L. Grapes, R. L. Lensing, M. F. Rothschild, and C. H. Stahl. 2006. Genetic background influences metabolic response to dietary phosphorus restriction. J. Nutr. Biochem. 17:385-395. doi:10.1016/j.jnutbio.2005.08.008.

Jondreville, C., and J.-Y. Dourmad. 2005. Le phosphore dans la nutrition des porcs. (In French.) INRA Prod. Anim. 18:183-192.

Jondreville, C., P. S. Revy, J. Y. Dourmad, Y. Nys, S. Hillion, F. Pontrucher, J. Gonzalez, J. Soler, R. Lizardo, and J. Tibau. 2004. Influence du sexe et du génotype sur la rétention corporelle de calcium, phosphore, potassium, sodium, magnésium, fer, zinc et cuivre chez le porc de 25 à $135 \mathrm{~kg}$ de poids vif. (In French.) Journ. Rech. Porcine Fr., [C. R.] 36:17-24.

Jongbloed, A. W., and H. Everts. 1992. Apparent digestible phosphorus in the feeding of pigs in relation to availability, requirement and environment. 2 . The requirement of digestible phosphorus for piglets, growing-finishing pigs and breeding sows. Neth. J. Agric. Sci. 40:123-136.

Jongbloed, A. W., and Z. Mroz. 1997. Intestinal absorption and secretion of minerals along the digestive tract of pigs. In: J. P. LaPlace, C. Fevrier, and A. Barbeau, editors, Digest. Physiol. Pigs Proc. 7th Int. Symp., St. Malo, France. EAAP Publ. No 88. INRA, Paris. p. 288-299.

Ketaren, P. P., E. S. Batterham, E. B. Dettmann, and D. J. Farrell. 1993. Phosphorus studies in pigs. 3. Effect of phytase supplementation on the digestibility and availability of phosphorus in soya-bean meal for grower pigs. Br. J. Nutr. 70:289-311. doi:10.1079/BJN19930123.

Kornegay, E. T. 2001. Digestion of phosphorus and other nutrients: The role of phytases and factors influencing their activity. In: M. R. Bedford and G. G. Partridge, editors, Enzymes in farm animal nutrition. CAB International, Wallingford, UK. p. 237-271.

Lantzsch, H. J., S. Wjst, and W. Drochner. 1995. The effect of dietary calcium on the efficacy of microbial phytase in rations for growing pigs. J. Anim. Physiol. Anim. Nutr. 73:19-26. doi:10.1111/j.1439-0396.1995.tb00399.x.

Larsen, T., and B. Sandström. 1993. Effect of dietary calcium level on mineral and trace element utilization from a rapeseed (Brassica napus L.) diet fed to ileum-fistulated pigs. Br. J. Nutr. 69:211-224. doi:10.1079/BJN19930023.

Létourneau-Montminy, M. P., C. Jondreville, D. Sauvant, and A. Narcy. 2012. Meta-analysis of phosphorus utilization by growing pigs: Effect of dietary phosphorus, calcium and exogenous phytase. Animal 6:1590-1600. doi:10.1017/ S1751731112000560.

Létourneau-Montminy, M. P., P. Lovatto, and C. Pomar. 2014. The intestinal absorption of dietary calcium and phosphorus and their efficiency in bone mineral retention are affected by body mineral status in growing pigs. J. Anim. Sci. 92:3914-3924. doi:10.2527/jas.2013-7320.

Létourneau-Montminy, M. P., and A. Narcy. 2013. Meta-analysis of the impact of dietary phosphorus, calcium, and microbial phytase on growth performance in pigs. J. Anim. Sci. 91(Suppl. 2):100 (Abstr.).

Létourneau-Montminy, M. P., A. Narcy, P. Lescoat, J. F. Bernier, M. Magnin, D. Sauvant, C. Jondreville, and C. Pomar. 2011. Modeling the fate of dietary phosphorus in the digestive tract of growing pigs. J. Anim. Sci. 89:3596-3611. doi:10.2527/ jas.2010-3397.

Létourneau-Montminy, M. P., A. Narcy, M. Magnin, D. Sauvant, J. F. Bernier, C. Pomar, and C. Jondreville. 2010. Effect of reduced dietary calcium concentration and phytase supplementation on calcium and phosphorus utilization in weaned piglets with modified mineral status. J. Anim. Sci. 88:17061717. doi:10.2527/jas.2008-1615.
Lyberg, K., A. Simonsson, and J. E. Lindberg. 2005. Influence of phosphorus level and soaking of food on phosphorus availability and performance in growing-finishing pigs. Anim. Sci. 81:375-381. doi:10.1079/ASC50460375.

Mahan, D. C. 1978. Protein, calcium and phosphorus requirements for young swine. In: Maryland Nutrition Conference Proc., University of Maryland, College Park, MD. p. 1-7.

Mahan, D. C., and R. G. Shields Jr. 1998. Macro- and micromineral composition of pigs from birth to 145 kilograms of body weight. J. Anim. Sci. 76:506-512.

Murry, A. C. 1995. Effect of microbial phytase on calcium and phosphorus digestibility and serum mineral concentrations in growing and finishing pigs. Animal \& Dairy Science Department Annual Report, University of Georgia, Athens, GA.

Narcy, A., M. P. Létourneau-Montminy, E. Bouzouagh, N. Même, M. Magnin, and J. Y. Dourmad. 2010. Effect of dietary calcium concentration and microbial phytase addition on P utilisation and growth performance in weaned pigs. J. Anim. Sci. 88(Suppl. 2):1007 (Abstr.).

Narcy, A., M. P. Létourneau-Montminy, E. Bouzouagh, N. Même, M. Magnin, and J. Y. Dourmard. 2012. Modulation de l'utilisation digestive du phosphore chez le porcelet sevré: Influence de l'apport de calcium et de phytase sur le $\mathrm{pH}$ et la solubilité des minéraux au niveau gastro-intestinal. (In French.) Journ. Rech. Porcine Fr., [C. R.] 44:159-164.

Nielsen, A. 1973. Anatomical and chemical composition of Danish Landrace pigs slaughtered at 90 kilograms live weight in relation to litter, sex and feed composition. J. Anim. Sci. 36:476-482.

NRC. 2012. Nutrient requirements of swine. 11th ed. Natl. Acad. Press, Washington, DC.

Pallauf, J., G. Rimbach, S. Pippig, B. Schindler, and E. Most. 1994. Effect of phytase supplementation to a phytate-rich diet based on wheat, barley and soya on the bioavailability of dietary phosphorus, calcium, magnesium, zinc and protein in piglets. Agribiol. Res. 47:39-48.

Parfitt, A. M. 1976. The actions of parathyroid hormone on bone: Relation to bone remodeling and turnover, calcium homeostasis, and metabolic bone disease. 1. Mechanisms of calcium transfer between blood and bone and their cellular basis: Morphological and kinetic approaches to bone turnover. Metabolism 25:809-844. doi:10.1016/0026-0495(76)90151-7.

Petersen, G. I., and H. H. Stein. 2006. Novel procedure for estimating endogenous losses and measurement of apparent and true digestibility of phosphorus by growing pigs. J. Anim. Sci. 84:2126-2132. doi:10.2527/jas.2005-479.

Pettey, L. A., G. L. Cromwell, and M. D. Lindemann. 2006. Estimation of endogenous phosphorus loss in growing and finishing pigs fed semi-purified diets. J. Anim. Sci. 84:618-626.

Platt, B. S., and R. J. Stewart. 1962. Transverse trabeculae and osteoporosis in bones in experimental protein-calorie deficiency. Br. J. Nutr. 16:483-495. doi:10.1079/BJN19620047.

Pointillart, A., and N. Fontaine. 1983. Effet de deux régimes hypocalcémiants sur la rétention et l'absorption du phosphore et du calcium chez le porc en croissance. (In French.) Journ. Rech. Porcine Fr., [C. R.] 15:375-384.

Pointillart, A., A. Fourdin, and A. Delmas. 1987. Conséquences néfastes de l'excès de calcium chez des porcs non supplémentés en phosphore minéral. (In French.) Journ. Rech. Porcine Fr., [C. R.] 19:281-288.

Pomar, C., D. L. Harris, and F. Minvielle. 1991a. Computer simulation model of swine production systems: I. Modeling the growth of young pigs. J. Anim. Sci. 69:1468-1488. 
Pomar, C., D. L. Harris, and F. Minvielle. 1991b. Computer simulation model of swine production systems: II. Modeling body composition and weight of female pigs, fetal development, milk production, and growth of suckling pigs. J. Anim. Sci. 69:1489-1502.

Pomar, C., D. L. Harris, P. Savoie, and F. Minvielle. 1991c. Computer simulation model of swine production systems: III. A dynamic herd simulation model including reproduction. J. Anim. Sci. 69:2822-2836.

Pomar, C., C. Jondreville, J.-Y. Dourmad, and J. Bernier. 2006. Influence du niveau de phosphore des aliments sur les performances zootechniques et la rétention corporelle de calcium, phosphore, potassium, sodium, magnésium, fer et zinc chez le porc de 20 à $100 \mathrm{~kg}$ de poids vif. (In French.) Journ. Rech. Porcine Fr., [C. R.] 38:209-216.

Pomar, C., and M. Marcoux. 2005. The accuracy of measuring backfat and loin muscle thickness on pork carcasses by the Hennessy hgp2, Destron pg-100, CGM and ultrasound CVTgrading probes. Can. J. Anim. Sci. 85:481-492. doi:10.4141/A05-041.

Quiniou, N., and J. Noblet. 1995. Effect of energy intake on performance, nutrient and tissue gain and protein and energy utilization in growing boars. Anim. Sci. 61:133-143. doi:10.1017/S1357729800013618.

Reinhard, M. K., D. C. Mahan, B. L. Workman, J. H. Cline, A. W. Fetter, and A. P. Grifo. 1976. Effects of increasing dietary protein level, calcium and phosphorus on feedlot performance, bone mineralization and serum mineral values with growing swine. J. Anim. Sci. 43:770-780.

Reinhart, G. A., and D. C. Mahan. 1986. Effect of various calcium:phosphorus ratios at low and high dietary phosphorus for starter, grower and finishing swine. J. Anim. Sci. 63:457-466.

Rodehutscord, M., M. Faust, and E. Pfeffer. 1999. The course of phosphorus excretion in growing pigs fed continuously increasing phosphorus concentrations after a phosphorus depletion. Arch. Anim. Nutr. 52:323-334.

Rodehutscord, M., R. Haverkamp, and E. Pfeffer. 1998. Inevitable losses of phosphorus in pigs, estimated from balance data using diets deficient in phosphorus. Arch. Anim. Nutr. 51:27-38.

Rousseau, X. 2013. Optimisation de l'utilisation de phosphore alimentaire chez le porc et le poulet en croissance. (In French.) $\mathrm{PhD}$ Thesis. Université François-Rabelais, Tours, France.

Ryan, W. F., P. B. Lynch, and J. V. O’Doherty. 2011. Compensatory effect of dietary phosphorus on performance of growing pigs and development of bone mineral density assessed using dual energy x-ray absorptiometry. Livest. Sci. 138:89-95. doi:10.1016/j.livsci.2010.12.006.

Rymarz, A., H. Fandrejewski, and J. Kielanowski. 1982. Content and retention of calcium, phosphorus, potassium and sodium in the bodies of growing gilts Norwegian Landrace, Large White and Hampshire. Livest. Prod. Sci. 9:399-407. doi:10.1016/0301-6226(82)90045-8.

Sauvant, D., J. M. Perez, and G. Tran. 2004. Tables of composition and nutritional value of feed materials. Institut National de la Recherche Agronomique, Association Française de Zootechnie, Paris.

Sauvant, D., P. Schmidely, and J. J. Daudin. 2005. Méta-analyse des données expérimentales: Applications en nutrition animales. (In French.) INRA Prod. Anim. 18:63-73.

Schneider, H., and H. Steenbock. 1939. A low phosphorus diet and the response of rats to vitamin $\mathrm{D}_{2}$. J. Biol. Chem. 128:159-172.

Schulin-Zeuthen, M., E. Kebreab, W. J. Gerrits, S. Lopez, M. Z. Fan, R. S. Dias, and J. France. 2007. Meta-analysis of phosphorus balance data from growing pigs. J. Anim. Sci. 85:1953-1961. doi:10.2527/jas.2006-715.
Selle, P. H., A. J. Cowieson, and R. Ravindran. 2009. Consequences of calcium interactions with phytate and phytase for poultry and pigs. Livest. Sci. 124:126-141. doi:10.1016/j.livsci.2009.01.006.

Selle, P. H., and V. Ravindran. 2008. Phytate-degrading enzymes in pig nutrition. Livest. Prod. Sci. 113:99-122. doi:10.1016/j. livsci.2007.05.014.

Shen, Y., M. Z. Fan, A. Ajakaiye, and T. Archbold. 2002. Use of the regression analysis technique to determine the true phosphorus digestibility and the endogenous phosphorus output associated with corn in growing pigs. J. Nutr. 132:1199-1206.

Spencer, J. D., G. L. Allee, and T. E. Sauber. 2000. Phosphorus bioavailability and digestibility of normal and genetically modified low-phytate corn for pigs. J. Anim. Sci. 78:675-681.

Stauffer, M., D. Baylink, J. Wergedal, and C. Rich. 1972. Bone repletion in calcium deficient rats fed a high calcium diet. Calcif. Tissue Res. 9:163-172. doi:10.1007/BF02061954.

Stein, H. H., L. Adeola, G. L. Cromwell, S. W. Kim, D. C. Mahan, and P. S. Miller. 2011. Concentration of dietary calcium supplied by calcium carbonate does not affect the apparent total tract digestibility of calcium, but decreases digestibility of phosphorus by growing pigs. J. Anim. Sci. 89:2139-2184. doi:10.2527/jas.2010-3522.

Stein, H. H., C. T. Kadzere, S. W. Kim, and P. S. Miller. 2008. Influence of dietary phosphorus concentration on the digestibility of phosphorus in monocalcium phosphate by growing pigs. J. Anim. Sci. 86:1861-1867. doi:10.2527/jas.2008-0867.

Suttle, N. F. 2010. Mineral nutrition of livestock, 4th ed. CABI Publ., Wallingford, UK.

Theil, H. 1966. Applied Economic Forecasting. North-Holland Publishing Company, Amsterdam, the Netherlands.

Thornley, J. H. M., and J. France, editors. 2006. Mathematical models in agriculture. quantitative methods for the plant, animal and ecological sciences. CABI Publ., Wallingford, UK.

Underwood, E. J., and N. F. Suttle. 1999. The Mineral Nutrition of Livestock 3rd Ed. CABI Publishing, CAB International, Wallingford, Oxon, UK.

van Milgen, J., A. Valancogne, S. Dubois, J.-Y. Dourmad, B. Sève, and J. Noblet. 2008. InraPorc: A model and decision support tool for the nutrition of growing pigs. Anim. Feed Sci. Technol. 143:387-405. doi:10.1016/j.anifeedsci.2007.05.020.

Varley, P. F., J. J. Callan, and J. V. O'Doherty. 2011a. Effect of dietary phosphorus and calcium level and phytase addition on performance, bone parameters, apparent nutrient digestibility, mineral and nitrogen utilization of weaner pigs and the subsequent effect on finisher pig bone parameters. Anim. Feed Sci. Technol. 165:201-209. doi:10.1016/j.anifeedsci.2011.02.017.

Varley, P. F., B. Flynn, J. J. Callan, and J. V. O'Doherty. 2011b. Effect of crude protein and phosphorus level on growth performance, bone mineralisation and phosphorus, calcium and nitrogen utilisation in grower-finisher pigs. Arch. Anim. Nutr. 65:134-147. doi:10.1080/1745039X.2011.556327.

Veum, T. L., D. R. Ledoux, V. Raboy, and D. S. Ertl. 2001. Lowphytic acid corn improves nutrient utilization for growing pigs. J. Anim. Sci. 79:2873-2880.

Vipperman, P. E., Jr., E. R. Peo Jr., and P. J. Cunningham. 1974. Effect of dietary calcium and phosphorus level upon calcium, phosphorus and nitrogen balance in swine. J. Anim. Sci. 38:758-765.

Whittemore, C. T., and R. H. Fawcett. 1976. Theoretical aspects of a flexible model to stimulate protein and lipid growth in pigs. Anim. Prod. 22: 87-96.

Whittemore, C. T. 1983. Development of recommended energy and protein allowances for growing pigs. Agric. Syst. 11:159-186. doi:10.1016/0308-521X(83)90072-0. 
Wiseman, T. G., D. C. Mahan, and N. St-Pierre. 2009. Mineral composition of two genetic line of barrows and gilts from twenty to one hundred twenty-five kilograms of body weight. J. Anim. Sci. 87:2306-2314. doi:10.2527/jas.2006-545.

Zhang, G. H., J. Pomar, C. Pomar, and J. Del Castillo. 2012. L'alimentation de précision chezle porc charcutier: Estimation des niveaux dynamiques de lysine digestible nécessaires à la maximisation du gain de poids. (In French.) Journ. Rech. Porcine Fr., [C. R.] 44:171-176.
Zimmermann, A. N., H. J. Lantzch, R. Mosenthin, H. K. Biesalski, and W. Drochner. 2003. Additivity of the effect of cereal and microbial phytases on apparent phosphorus absorption in growing pigs fed diets with marginal P supply. Anim. Feed Sci. Technol. 104:143-152. doi:10.1016/S0377-8401(02)00291-2.

Zimmermann, B., H. J. Lantzsch, R. Mosenthin, F. J. Schöner, H. K. Biesalski, and W. Drochner. 2002. Comparative evaluation of the efficacy of cereal and microbial phytases in growing pigs fed diets with marginal phosphorus supply. J. Sci. Food Agric. 82:1298-1304. doi:10.1002/jsfa.1190. 